UNIVERSIDADE DE SÃO PAULO

FACUDADE DE ODONTOLOGIA DE RIBEIRÃO PRETO

\title{
Resistência à corrosão de ligas metálicas com diferentes porcentagens de Jitânio para uso odontológico
}

Ribeirão Preto 2006 


\section{FICHA CATALOGRÁFICA}

Pires-de-Souza, Fernanda de Carvalho Panzeri

Resistência à corrosão de ligas metálicas com diferentes porcentagens de Titânio para uso odontológico. Ribeirão Preto, 2006.

115 p. : il. ; $30 \mathrm{~cm}$

Tese (Livre-Docência), apresentada à Faculdade de Odontologia de Ribeirão Preto/USP - Departamento de Materiais Dentários e Prótese.

1. Fundição Odontológica. 2. Resistência à corrosão. 3. Ligas Odontológicas. 


\section{Dedicatória}


$G$ raças, S enhor, porque T eu éo êxito obtido. 
国adecimentos speciais 


\section{Agradecimentos Ëspeciais}

A meu marido, $F$ rancisco $T$ eodorico $P$ ires de $S$ ouza, por tudo.

$P$ or sua paciência e sua compreensão. $P$ or me dar forças para sempre continuar. $\mathrm{P}$ or me tornar uma pessoa mel hor. $\mathrm{P}$ or me amar quando eu mais preciso, que é o momento que menos mereço.

A minha amiga $L$ uciana $A$ ssirati $C$ asemiro pel 0 auxílio nesse trabal ho e por todos os momentos de convivência. N ossa amizade é como uma estrela no horizonte.N ão a vemos em todos os momentos, mas sabemos que el a está sempre lá.

A minha mãe, $\mathrm{N}$ eusa de $\mathrm{C}$ arval ho $\mathrm{P}$ anzeri, pel 0 exemplo de I uta e dedicação. P or todo 0 seu amor e doação. P or ser uma pessoa digna e fiel, o que muito me orgul ha. 
A vid a é generosa e, a cad a sal a que se vive, descobre se tan tas outras portas. E a vid a enriquece quem se arrisca a abrir novas portas. P ara a vida, as portas não são obstácul os, mas diferentes passagens! (I çami T iba)

\begin{abstract}
A P rofa. D ra. M aria da G lória C hiarello de M attos pela cessão do equipamento util izado no trabal ho e por todo apoio em minha carreira. 0 brigada pel as oportunidades de sempre aprender.
\end{abstract}

A OD outorando R odigo $G$ al o por toda a sua contribuição na real ização desse trabal ho. S ua participação foi fundamental. 0 brigada por toda a sua disponibilidade e pel os momentos em que aprendemos muito mais do que a $\mathrm{C}$ iência pode nos ensinar. 
Q uem caminha sozinho pode até chegar mais rápido, mas aquel e que vai acompanhado com certeza chegará

mais I onge

(A utor D esconhecido)

A o S r.J osé de $G$ odoy $F$ ilho, pel o auxílio na obtenção das fundições. M esmo após muitas dificuldades, as mãos estavam sempre estendidas em minha direção. M uito obrigada.

A o S r. F rancisco $L$ ourenço $F$ erreira $R$ oselino por toda a convivência e auxílio diário. $S$ eus pequenos gestos sempre se transformam em grandes obras para mim. M uitas vezes, foi você quem viu as lágrimas em meu rosto e o sorriso em meus lábios.

M uito obrigada. 
Igradecimentos 
A prender é a única coisa de que a mente nunca se cansa, nunca tem med 0 e nunca se arrepende. ( $L$ eon ardo da $V$ inci)

\section{Rgradecimentos}

A Profa. Dra. Marisa Semprini, Diretora da FORP, pela amizade e apoio em todos os momentos.

A todos os docentes do Departamento de Materiais Dentários e Prótese, pela amizade e companheirismo no caminhar.

A todos os amigos, docentes e funcionários da FORP, por toda colaboração e parceria.

Aos Servidores não-docentes do Departamento de Materiais Dentários e Prótese da Faculdade de Odontologia de Ribeirão Preto da USP, "nossos" técnicos e funcionários, Regiane de Cássia Tirado Damasceno, Ana Paula Xavier, Francisco Lourenço Femeira Roselino, Paulo Sérgio Femeira, Paulo César Teodoro, Marcelo Aparecido Vieira, Lício Fimino Júnior, Femando Schiavetto, José de Godoi Filho, José Hennique Loureiro, Luiz Sérgio Soares, Odair Rosa da Silva, Eduardo Destito, Ana Paula Macedo e José Carlos Ferreira Júnior, por todo o auxílio e amizade. Nós, docentes, não subiríamos os degraus da carreira sem o auxílio de vocês, 
Aos Estagiários Brahim Drubi Filho, Cristiane Femandes Canalho e Lucas da Fonseca Roberti Garcia; orientados de PósGraduação Hisham Mohamad Hamida, Fabrício Mariano Mundim, Sônia Maria Lemos Brancatto Camaninha e Fabiano Gamero Aguilar, e orientados de Iniciação Científica Diogo Rodrigues Cruvinel, Manlia Daniela Busnardo Canadas, Thiago Cuellar e Gustavo Frasnelli. Tantas vezes aprendi muito mais do que ensinei. Obrigada pela confiança depositada em mim e pela paciência nos momentos em que não pude corresponder às expectativas de cada um. Sem a compreensão de vocês esse trabalho não teria ficado pronto. Vocês todos são um incentivo em minha vida para que eu sempre busque novos caminhos.

$T$ odo ramo que não der fruto em mim, $E$ le 0 cortará; e podará todo o que der fruto para que produza mais fruto.

(J esus C risto segundo J oão 15: 1-2)

A todos que, de qualquer forma, tenham contribuído para que eu pudesse realizar esse trabalho de maneira digna, 
Uma das melhoses maneiras de dar um sentida pasa a vida é procuras deixar a munda um pouca melhor da que nás a encontramos. (Sal Gardan) 


\section{Resumo}

Pires-de-Souza, FCP. Resistência à corrosão de ligas metálicas com diferentes porcentagens de Titânio para uso odontológico. Departamento de Materiais Dentários e Prótese. Faculdade de Odontologia de Ribeirão Preto, Universidade de São Paulo. Tese (LivreDocência), Ribeirão Preto, 2006. 115p.

A utilização de metais ou ligas metálicas para restaurações odontológicas baseia-se em um conjunto de características ou propriedades que os tornam compatíveis com o uso. Na maioria das vezes, no conjunto das propriedades, estão envolvidas resistência mecânica, biocompatibilidade, mas, fundamentalmente, a resistência à corrosão. O titânio é um metal que apresenta elevado índice de resistência à corrosão. A adição deste metal em concentrações diferentes pode acarretar em um caráter de excelência. Dessa forma, o objetivo deste trabalho foi avaliar in vitro a resistência à corrosão e condição superficial de três ligas a base de $\mathrm{Ni} / \mathrm{Cr}$ com diferentes porcentagens de Ti adicionado utilizadas com finalidade odontológica. Foram selecionadas três ligas com porcentagens diferentes de Ti: VAT80A $(2,4 \%)$, Inconel X $750(2,5 \%)$, Waspaloy $(3,0 \%)$, além de uma liga de $\mathrm{Ni} / \mathrm{Cr}$ (Verabond). Os 10 corpos-de-prova $(15 \mathrm{~mm}$ de diâmetro e $3 \mathrm{~mm}$ de espessura) de cada liga foram obtidos pela técnica da cera perdida e as ligas foram fundidas com maçarico gás/ar. Em seguida, as amostras foram submetidas ao ensaio de polarização anódica, seguido de análise superficial em Microscopia Eletrônica de Varredura (MEV). Os resultados foram submetidos à análise estatística (ANOVA - Tukey - nível de significância de 95\%) e permitiram verificar que houve diferença estatisticamente significante no comportamento corrosivo entre as ligas. A liga Verabond apresentou maior resistência à corrosão e a liga Waspaloy foi o material que apresentou menor resistência. Após a corrosão as ligas apresentaram-se com vários graus de rugosidade e porosidade, sendo que para as ligas Verabond e Waspaloy foi possível observar segregação de fases. Concluiu-se que a corrosão de uma liga está diretamente ligada à sua composição e que a quantidade de Ti adicionado interferiu na resistência à corrosão de ligas para uso odontológico. 


\begin{abstract}
Pires-de-Souza, FCP. Corrosion resistance of metal alloys with different percentages of titanium for dental use. Department of Dental Materials and Prosthodontics. Ribeirão Preto Dental School, University of São Paulo. Associate Professorship Thesis, Ribeirão Preto, 2006. 115p.
\end{abstract}

Whether or not particular metals or metal alloys are appropriate for dental restorations is based upon a group of characteristics or properties. Mechanical strength and biocompatibility are usually included in this group of properties. Corrosion resistance, however, is a fundamental item. Titanium (Ti) is a metal with a high corrosion resistance index. Adding different concentrations of this metal may lead to the development of an excellent alloy. Hence, this work aims to evaluate in vitro the corrosion resistance and surface condition of three Ni/Cr-based alloys with different percentages of Ti added for dental use: VAT80A (2.4\%), Inconel X 750 (2.5\%), Waspaloy (3.0\%), and a Ni/Cr alloy (Verabond). Ten specimens (15 $\mathrm{mm}$ in diameter and $3 \mathrm{~mm}$ in thickness) for each alloy were obtained by the lost wax technique. The alloys were cast with a gas/air system. Next, the specimens were subjected to the anodic polarization technique, followed by surface analysis using Scanning Electron Microscopy (SEM). Results were submitted to statistical analysis (ANOVA - Tukey - level of significance of 95\%) and showed that there was a statistically significant difference in the corrosive behavior between the alloys. The Verabond alloy showed higher corrosion resistance, and the Waspaloy alloy had the lowest resistance. After corrosion, the alloys showed different levels of roughness and porosity. Phase segregation was observable in the Verabond and Waspaloy alloys. It is concluded that the corrosion of an alloy is directly associated with its composition, and that the quantity of Ti added interfered with the corrosion resistance of dental alloys. 


\section{Sumánio}

Resumo 13

Abstract

1. Introdução _ 16

2. Revisão da Literatura 21

2.1 - Noções Básicas de Corrosão __ 22

2.2. - Polarização_ 28

2.3 - Ligas Odontológicas __ 32

2.4 - O titânio e suas ligas __ 41

3. Proposição__ 53

4. Material e Métodos _ 55

4.1 - Obtenção dos corpos-de-prova_ 56

4.2 - Resistência à corrosão 60

4.3 - Solução eletrolítica 64

4.4 - Análise da morfologia superficial __ 65

5. Resultados 66

5.1 - Potencial em Circuito Aberto (Eocp)__ 67

5.2 - Potencial $\mathrm{E}_{\mathrm{i}}=0 \ldots 70$

5.3 - Corrente de corrosão (icorr) 71

5.4 - Análise morfológica superficial __ 74

6. Disc ussão _ 80

7. Conclusão _ 101

8. Referências Bibliográficas___ 104 
1. Sెntrodução 


\section{Introdução}

A utilização de metais ou ligas metálicas para restaurações odontológicas baseia-se em um conjunto de características ou propriedades que os tornam compatíveis com o uso. Devem-se considerar seus aspectos biológicos, estruturais, físicos e tecnológicos. Dentre esses aspectos, deve-se destacar a resistência à corrosão que é sempre um fator considerado como principal devido à sua influência na resistência à fratura e na estética da reabilitação protética.

O ouro, isoladamente, ou associado aos metais nobres (prata, paládio, platina) são as referências porque, independentemente de seus valores de resistência mecânica, são insuperáveis quanto à resistência à corrosão e isto caracteriza o que se convencionou chamar de metal nobre.

A corrosão é definida pela Norma ISO/10271 (2001) como uma interação físico-química entre um metal ou uma liga e seu meio, resultando em uma destruição parcial ou total do metal ou em uma alteração de suas propriedades. O produto da corrosão é uma substância formada como resultado desse processo. A dissolução dos íons metálicos causada pela corrosão pode diminuir as propriedades mecânicas das ligas, resultando em quebra e fraturas do metal (GEISGERSTORFER, 1994). 
Uma condição essencial para que ocorra a corrosão é a necessidade de exposição do metal a um meio agressivo capaz de deteriorar a matéria (ANUSAVICE; CASCONE, 2005). O ambiente bucal, sendo tão variável em relação à presença da umidade, flutuação da temperatura, $\mathrm{pH}$ e dieta, contribui para que ocorra a corrosão em ligas metálicas. O termo corrosão é sempre utilizado para metais e seu mecanismo de ação é sempre químico ou eletroquímico (ADELL et al., 1981; GEIS-GERSTORFER, 1994).

A liga Vitallium, introduzida na Odontologia por volta de 1930, trouxe uma nova fonte de uso e assentou o uso de ligas e super-ligas à base de Cobalto/Cromo. Mais um passo e a indústria disponibilizava as ligas de $\mathrm{Ni} / \mathrm{Cr}$, que rapidamente ocupou espaço das ligas de ouro quanto à confecção de coroas e próteses fixas metalocerâmicas (MOFFA, 1983).

O níquel é um dos metais mais importantes usado como elemento de liga em aços e outras ligas. O níquel puro e suas ligas têm características importantes, como boa resistência mecânica e elevada ductilidade, mesmo a temperaturas baixas, responsáveis por sua ampla utilização.

É sabido que as ligas de Ni/Cr têm elevado valor de resistência mecânica e alta dureza. A resistência à corrosão é dada pelo cromo, que tem como característica básica a formação de uma camada de 
óxido na sua superfície. Esta camada também é chamada de passivadora. Passivação é o processo pela qual uma superfície é caracterizada pelo baixo coeficiente de corrosão em uma região potencial que é fortemente oxidante para o material (ANUSAVICE; CASCONE, 2005).

Durante todo o tempo, essas ligas têm sofrido modificações constantes de formulação e obtenção com vistas a melhorar suas qualidades. O surgimento das superligas é um exemplo disso. Segundo Costa e Silva; Mei (1988), superligas são ligas a base de Fe, Ni ou Co, contendo $\mathrm{Cr}$ para resistência à oxidação e corrosão e outros elementos para resistência mecânica a temperatura elevada. A introdução de titânio e alumínio nas superligas a base de $\mathrm{Ni}$ possibilita $\mathrm{O}$ endurecimento por precipitação e a adequação de outras propriedades importantes à sua indicação.

Grande parte do desenvolvimento das superligas pode ser creditada às necessidades decorrentes do desenvolvimento de turbinas a gás. Superligas possuem excelente resistência à corrosão e oxidação em diversos meios, notáveis propriedades mecânicas à altas temperaturas e elevada resistência à fadiga. Além disto, são projetadas para apresentar bom desempenho em condições cíclicas de aquecimento e resfriamento além de elevada resistência à fluência (COSTA E SILVA; MEI, 1988). 
O titânio é um metal que apresenta elevado índice de resistência à corrosão, que é baseada também no processo de passivação. Esse processo se dá devido a presença do ar levando a formação de uma camada de óxido aderente à superfície de $1 \mathrm{~mm}$ de espessura, que confere uma excelente resistência à corrosão em temperatura ambiente (HRUSKA; BORELLI, 1991). Porém, pouco se sabe do comportamento quanto à corrosão de ligas que contenham titânio em sua composição. 
2. Bevisão da Lîteratura 


\section{Revisão da Literatura}

\section{1 - Noções Básicas de Comosão}

Com base em livros textos sobre Corrosão (GENTIL, 1996; WOLYNEC, 2003), optou-se por fazer um apanhado geral de conceitos e oferecer noções básicas de corrosão e de eletroquímica para que esses conhecimentos sejam aplicados no estudo do comportamento das ligas odontológicas.

A corrosão é definida como a deterioração de um material, geralmente metálico, por ação química ou eletroquímica do meio ambiente aliada ou não a esforços mecânicos (GENTIL, 1996).

fenômeno exato da corrosão é, muitas vezes, complexo e não completamente entendido. Trata-se de um processo espontâneo e, não fora alguns mecanismos protetores, ter-se-ia a destruição completa dos materiais metálicos, já que os processos de corrosão são reações químicas e eletroquímicas que se passam na superfície do metal e obedecem a princípios bem estabelecidos.

Os fenômenos de corrosão de metais envolvem uma grande variedade de mecanismos que, no entanto, podem ser reunidos em quatro grupos (WOLYNEC, 2003):

Corrosão em meios aquosos (90\%)

Oxidação e corrosão quente (8\%) 
Corrosão em meios orgânicos $(1,8 \%)$

Corrosão por metais líquidos $(0,2 \%)$

Quanto menos homogêneo for o metal e mais complexo for o meio, mais complicado será o processo de corrosão. A composição, o estado físico e a condição de superfície do metal (GUILHERME et al., 2005), bem como os componentes químicos dos meios circundantes, determinam a natureza das reações de corrosão. Outras variáveis importantes que afetam o processo de corrosão são a temperatura e suas oscilações, o movimento ou a circulação do meio em contato com a superfície do metal, e a natureza e solubilidade dos produtos de corrosão (GEIS-GERSTORFER, 1994). A despeito de todas essas complexidades, se o mecanismo geral de corrosão for entendido, geralmente será possível reconhecer as variáveis que o controlam em um dado momento da corrosão.

Considerando-se como oxidação-redução todas as reações químicas que consistem em ceder ou receber elétrons, podem-se considerar os processos de corrosão como reações de oxidação dos metais, isto é, o metal age como redutor, cedendo elétrons que são recebidos por uma substância, o oxidante, existente no meio corrosivo. Logo, a corrosão é um modo de destruição do metal, progredindo 
através de sua superfície. Quando os metais reagem, têm tendência a perder elétrons, sofrendo oxidação e, assim, corrosão.

A imersão de um metal em soluções eletrolíticas determina o estabelecimento de uma diferença de potencial entre as duas fases, a sólida e a líquida. Esta diferença de potencial é, simultaneamente, de natureza elétrica e de natureza química, e por isso se denomina diferença de potencial eletroquímico. Uma reação é considerada eletroquímica quando ela está associada a uma passagem de corrente elétrica que envolve o movimento de partículas carregadas: íons, elétrons ou ambos.

Um eletrodo é denominado ânodo quando nele ocorre oxidação e onde a corrente elétrica, na forma de íons metálicos positivos, entra no eletrólito; um cátodo é um eletrodo no qual as cargas negativas (elétrons) provocam reações de redução, a corrente elétrica sai do eletrólito. Quando esses componentes estão imersos em um eletrólito a formação dos íons dentro da solução se inicia. Esses elétrons carregam eletricamente o metal e criam um campo elétrico dentro da solução, que faz com que os íons, que são carregados positivamente (ânodo), tendam a ficar retidos na vizinhança da interface metalsolução e, após algum tempo, forma-se a dupla camada (WEST, 1970).

A dupla camada de Helmholtz caracteriza-se por apresentar uma camada difusa de íons que se espalham por uma distância de 
aproximadamente 1 mícron (Fig. 1). O plano P, saturado com íons metálicos, é chamado de plano de Helmholtz externo, enquanto o plano Q, que forma a região em que os íons não solvatados (que não reagiram com o eletrólito) ou parcialmente solvatados podem ser especificamente adsorvidos, constitui o plano de Helmholtz interno. Como espécies carregadas eletricamente estão envolvidas, o resultado será uma distribuição desigual de cargas elétricas da qual se segue o aparecimento de uma diferença de potencial entre a superfície e o interior da solução. A queda de potencial entre o eletrodo e a solução pode ser controlada através de um circuito externo.

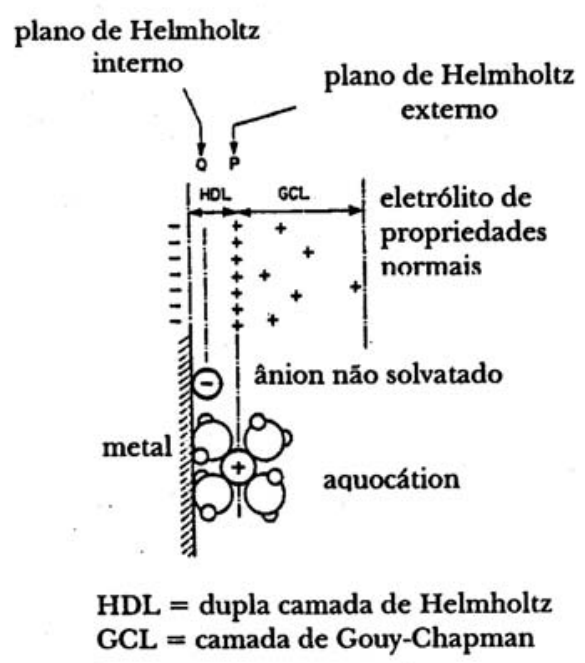

Figura 1 - Estrutura de dupla camada (Adaptada de (WOLYNEC, 2003)

Quando se tem um eletrodo constituído por um metal imerso em solução de seus íons, pode-se considerar o potencial do eletrodo como 
sendo E Este potencial será igual à diferença entre o potencial do metal Emetal e o potencial da solução $\mathbf{E}_{\text {solução. }} \bigcirc$ potencial de eletrodo normal não depende da concentração de íons na solução, representando, pois, uma característica própria do eletrodo. Para um potencial de eletrodo positivo, o metal apresenta tendência à redução ou aquisição de elétrons. Para um valor negativo do eletrodo, a tendência é para a oxidação ou perda de elétrons.

Assim, um determinado metal será tanto mais oxidável, ou apresentará maior tendência à perda de elétrons quanto mais negativo; tais metais dissolvem-se com facilidade. Ao contrário, quanto mais positivo for o valor do potencial de eletrodo normal, maior será a tendência de sofrer redução, ou de receber elétrons, ou de sofrer a deposição de íons; esses materiais são menos solúveis, menos oxidáveis e são considerados metais nobres.

O valor absoluto desse potencial é sempre medido a partir de um eletrodo de referência, como o de hidrogênio ou mesmo o calomelano. Os eletrodos de calomelano são constituídos por mercúrio em contato com cloreto mercuroso, estando o conjunto imerso em uma solução contendo cloreto de potássio. Trata-se de um eletrodo cujo potencial, em relação ao hidrogênio, é conhecido. Por exemplo, o potencial de um eletrodo de calomelano, em relação ao eletrodo normal de hidrogênio, é $+0,280 \mathrm{~V}$, e quando um determinado eletrodo tem a diferença de potencial de $+0,482 \mathrm{~V}$ em relação ao calomelano, 
conclui-se que o valor do potencial do eletrodo em relação ao eletrodo normal de hidrogênio é $+0,762 \mathrm{~V}$. Tem-se, assim, uma escala de medidas relativas, determinando-se então uma diferença de potencial. Embora esse eletrodo não seja tão preciso quanto os demais, é muito usado devido a ser mais resistente a choques e também menos sujeito a erros devidos à polarização.

oxigênio pode comportar-se como acelerador do processo eletroquímico de corrosão. Verifica-se que, em solução não-aeradas, a reação catódica se processa com velocidade muito pequena, sendo conseqüentemente o processo anódico também lento. No caso de meio não aerado, o hidrogênio pode ficar adsorvido na superfície do cátodo, polarizando a pilha formadora formada com conseqüente redução do processo corrosivo. Entretanto, no caso de meio aerado, tem-se a presença de oxigênio, ocorrendo a sua redução não havendo a polarização pelo hidrogênio e sim aceleração do processo corrosivo.

O oxigênio não funciona somente como estimulador de corrosão, podendo agir até certo ponto como protetor, pois é capaz de reagir diretamente com a superfície do metal formando camada de óxido protetor como, por exemplo, $\mathrm{Cr}_{2} \mathrm{O}_{3}, \mathrm{Al}_{2} \mathrm{O}_{3}, \mathrm{TiO}_{2}$, que retardará o contato do material com o meio corrosivo, e pode formar uma película de oxigênio adsorvida sobre o material metálico, tornando o metal passivo. 
Metais passivos, contudo, apresentam desvantagens. Forças de tensão e certos íons, como os cloretos, podem romper a película protetora, resultando em uma corrosão rápida.

\section{2. - Polanização}

Todo metal imerso em uma solução contendo seus próprios íons, na ausência de reações, possui um potencial E dado pela equação de Nernst. Se uma corrente circular por esse eletrodo, o potencial variará, e o novo valor de potencial E' dependerá da corrente aplicada. A diferença entre os dois potenciais é conhecida como sobrepotencial.

$$
\eta=E^{\prime}-E
$$

Pode ocorrer que o potencial inicial seja diferente do potencial de equilíbrio termodinâmico, devido a reações e fenômenos que interferem no processo. É o caso mais comum em corrosão, sendo esse valor conhecido como potencial de corrosão ou potencial misto. 0 potencial de corrosão também varia ao circular uma corrente pelo eletrodo, sendo esta variação conhecida como polarização.

Quando dois metais diferentes são ligados e imersos em um eletrólito, estabelece-se uma diferença de potencial entre os eletrodos resultantes. Fechando-se o circuito externo, observa-se uma diminuição dessa diferença de potencial com o tempo. O potencial do anodo se aproxima ao do cátodo, e do cátodo se aproxima ao do ânodo. Tem- 
se o que se chama polarização dos eletrodos, ou seja, polarização anódica no anodo e polarização catódica no cátodo.

Em princípio, poder-se-ia pensar que, quanto maior a diferença de potencial entre dois eletrodos, maior seria a velocidade de corrosão. No entanto, não se pode esquecer que o potencial é um parâmetro termodinâmico. A diferença de potencial entre dois eletrodos indica apenas quem atuará como cátodo e quem atuará como ânodo. A velocidade das reações anódica e catódica dependerá das características de polarização do sistema.

A velocidade média de corrosão pode ser obtida pela medida da diferença de peso apresentada pelo material metálico ou pela determinação da concentração de íons metálicos em solução durante intervalos de tempo de exposição ao meio corrosivo. A velocidade de corrosão de um metal pode ser medida também pela sua corrente de corrosão. A corrente de corrosão é igual à corrente anódica que circula no metal no potencial de corrosão ( $\left.E_{c o r r}\right)$.

Essa corrente não pode ser medida diretamente, porque no potencial de corrosão circula também, pelo metal, uma corrente catódica que tem valor igual ao da corrente anódica, porém, de sentido oposto. De modo que, se for ligado um amperímetro ao metal em $E_{c o r r} \mathrm{O}$ valor de corrente indicado pelo aparelho será sempre zero, embora o metal esteja corroendo e, portanto, nele circule uma corrente 
anódica. Sendo assim, a corrente de corrosão só pode ser determinado por métodos indiretos. Um método aplicado para esse fim baseia-se na extrapolação das retas de Tafel.

O produto n x i é a "força" que afasta um sistema eletroquímico de um estado de repouso. Esse produto será sempre positivo de modo que, quando o potencial varia, o valor do sobrepotencial criado define o comportamento do metal. Se o sobrepotencial for positivo, circulará pela interface metal-solução uma corrente positiva (corrente anódica), e o metal corroerá através de uma reação de oxidação. Se o sobrepotencial for negativo, isto é, se $E^{\prime}<E$, uma corrente catódica se estabelecerá, provocando uma reação de redução.

Para caracterizar a agressividade de um determinado meio corrosivo e fornecer fundamentos básicos para o controle da corrosão, realizam-se os chamados ensaios de corrosão.

A corrosão dos materiais metálicos é influenciada por vários fatores que modificam o ataque químico ou eletroquímico, não havendo, portanto, um único método de ensaio de corrosão. Entre os numerosos métodos de estudo da corrosão eletroquímica, a polarização é fundamental. Esse método consiste em realizar uma eletrólise, onde se utilizam, como eletrodo e eletrólito, respectivamente o metal e o meio cuja interação se deseja estudar. $\bigcirc$ ensaio pode ser conduzido a potenciais de eletrodo controlados (medindo-se os valores 
de corrente em função do potencial aplicado), ou então a corrente de eletrólise controlada (anotando-se os valores de potencial em função da corrente). Representando-se graficamente a relação entre E e I obtém-se uma curva de polarização.

As curvas de polarização, a potencial controlado, podem ser de dois tipos:

- Potenciocinética: É aquela onde se tem variação contínua ou em degraus do potencial de eletrodo, em função do tempo t. O registro imediato da corrente, em função da variação de potencial, implicará na obtenção de uma curva de polarização, que será a resposta do sistema àquela variação de potencial imposta externamente;

- Potenciostática: É aquela onde se tem variação descontínua do potencial de eletrodo, modificando-o ponto a ponto e medindo-se a corrente correspondente, após sua estabilização. Neste caso, os valores obtidos, chamados valores estacionários, não são em função do tempo.

As correntes, anódicas ou catódicas, freqüentemente são expressas como densidade de corrente (i), ou seja, corrente por unidade de área. 
Os ensaios eletroquímicos de corrosão em laboratório empregam equipamentos eletrônicos especiais como potenciostatos, fontes de tensão contínua, potenciômetros, registradores, miliamperímetros, voltímetros de posição e outros. O corpo-de-prova do material a ser estudado e o meio em que será feito o ensaio são colocados na chamada célula de polarização, onde se procura reproduzir, tanto quanto possível, as condições encontradas na prática para o tipo de estudo a ser conduzido no laboratório. Quando se estuda o mecanismo de um processo de corrosão em particular, tornase necessário controlar, durante o ensaio, todas as variáveis que possam ter algum efeito sobre o processo.

\section{3 - Ligas Odontológicas}

De um modo geral, as primeiras ligas metálicas empregadas na obtenção de restaurações odontológicas eram principalmente a base de ouro. Estas ligas, pesquisadas desde o início do século XX possuíam diferentes composições para diferentes tipos de emprego: inlay, onlay, próteses parciais fixa e removível (MONDELLI, 1995; BARAN, 2004).

A partir da década de 50 houve um grande avanço na fabricação de ligas odontológicas, principalmente quanto à união a porcelana. As ligas áureas mostravam-se insatisfatórias por possuírem coeficiente de expansão térmica muito maior do que o das porcelanas 
disponíveis no mercado. Porém, devido a problemas da alta do preço do ouro no final da década de 60, houve a necessidade de desenvolver ligas de metais básicos capazes de proporcionar uma alternativa viável aos tratamentos reabilitadores (WINKLER et al., 1984).

As ligas de Ni/Cr tornaram-se as mais utilizadas em próteses fixas por serem mais fáceis de fundir e permitir usinagem e acabamento, além de possuírem propriedades mecânicas superiores aos demais sistemas de ligas e atuarem muito bem quando empregadas como substrato à porcelana em restaurações metalocerâmicas devido ao fato de possuírem coeficiente de expansão térmica similar à cerâmica e alto ponto de fusão, o que permite a cocção de porcelanas de baixa fusão sem sofrer deformação (ANUSAVICE; CASCONE, 2005).

As ligas do sistema Ni/Cr possuem em média 70 a $80 \%$ de níquel (Ni) e de 13 a $22 \%$ de cromo ( $\mathrm{Cr}$ ), sendo incorporados outros elementos metálicos em menor quantidade para melhorar algumas propriedades físicas e mecânicas dessas ligas. De acordo com Mondelli (1995), os elementos metálicos presentes e suas respectivas concentrações são:

- Molibdênio: 4 a 10\%

- Alumínio: 2 a $4 \%$

- Manganês: 0,2 a $1 \%$

- Titânio: 0,1 a $2 \%$

- Carbono: 0,5 a $1,5 \%$ 
- Berílio: 0,5 a $2 \%$

- Silício: 0,5 a $1,5 \%$

- Cobalto: 0,5 a $2,5 \%$

- Ferro: 0,5 a $2,5 \%$

Na formulação deste sistema de ligas, o níquel é o elemento base por ser um metal relativamente mole e maleável, podendo tornar tais ligas mais dúcteis que as do sistema cobalto-cromo (Co/Cr) (HARCOURT et al., 1970).

O cromo é o terceiro elemento mais duro encontrado na natureza, só sendo inferior ao boro e ao diamante. Como elemento de liga tem como função aumentar a resistência à corrosão, à oxidação e ao manchamento, ou seja, aumentar a estabilidade superficial devido à formação de óxido de cromo. Porém, se a liga possuir uma quantidade maior, em peso, do que $30 \%$ deste elemento, a fundição tornar-se-á muito difícil e, durante a solidificação da liga, ocorrerá a formação indesejável de fase $\sigma$ (sigma) que tornará a liga quebradiça. Dentro das proporções corretas, o cromo também aumenta a resistência mecânica da solução sólida obtida durante a fusão destes elementos (MONDELLI, 1995).

O elemento molibdênio é um endurecedor efetivo da solução sólida; quando incorporado na proporção em peso de 3 a $6 \%$ aumenta 
a propriedade de resistência mecânica da liga. Também contribui com o aumento da resistência à corrosão (BARAN, 2004).

O alumínio, bem como o titânio, se precipitam na fase $Y^{\prime}$ e são importantes às superligas de $\mathrm{Ni} / \mathrm{Cr}$ conferindo a elas características básicas: resistência mecânica, resistência à fluência em altas temperaturas (creep), aumenta a resistência máxima à tração e o limite de proporcionalidade bem como a dureza superficial (MORRIS et al., 1992).

manganês aumenta a fundibilidade e também a resistência à corrosão e, se houver a presença de silício, esta propriedade é duplicada (MONDELLI, 1995).

O elemento carbono é um dos mais críticos constituintes da liga. Sua proporção deve ser bem balanceada pois, se estiver em quantidade maior do que a recomendada, cerca de 0,2\%, diminuirá a resistência mecânica e tornará a liga friável (MORRIS et al., 1992). Em pequenas proporções, se combina com outros constituintes reativos: cromo, molibdênio, silício, titânio, cobalto, níquel, presentes nas ligas odontológicas formando carbetos metálicos, principalmente durante o resfriamento da liga (MILLER, 1966). Durante tratamentos térmicos ou quando a liga é submetida a esforços mecânicos, estes carbetos se decompõem e dão origem a outros carbetos. Estes compostos exercem os efeitos deletérios citados, porém em discreta quantidade podem 
aumentar a resistência à ruptura, principalmente quando a liga estiver submetida a altas temperaturas.

O berílio participou da composição de várias ligas de Ni/Cr, com a finalidade de diminuir o ponto de fusão. Quando incorporado na proporção de 1 a 2\% em massa, fazia com que a temperatura de fusão abaixasse cerca de $100^{\circ} \mathrm{C}$ (BARAN, 2004). Este elemento metálico, altamente reativo, forma uma camada protetora que inibe a excessiva oxidação do cromo (MCLEAN, 1983). É um agente endurecedor e também promove um refinamento da estrutura granular. Porém, sua incorporação à composição destas ligas tornou-se contestável devido a problemas relativos à biosegurança quando da manipulação desse material pelos técnicos em prótese, devido à toxicidade da inalação de resíduos oriundos do acabamento e polimento das ligas fundidas.

O elemento silício participa da composição das ligas de $\mathrm{Ni} / \mathrm{Cr}$ tornando maior a fluidez e fundibilidade destas. Também age como desoxidante (HARCOURT et al., 1970). Quando incorporado em até 3,5\% pode aumentar a ductibilidade destas ligas, além de participar como endurecedor da solução sólida, assim como o ferro, incorporado em pequenas quantidades (ANUSAVICE; CASCONE, 2005).

No sistema de ligas $\mathrm{Ni} / \mathrm{Cr}$, o cobalto e o níquel, acima de determinada quantidade, são elementos intercambiáveis, sendo que o 
cobalto aumenta o módulo de elasticidade, a resistência e a dureza da liga (BARAN, 2004).

Nas diferentes composições das ligas de $\mathrm{Ni} / \mathrm{Cr}$ podem-se encontrar outros elementos como, por exemplo, o boro, o magnésio, o nióbio. O magnésio age como endurecedor e como agente desoxidante, tal qual a sílica; o boro também atua como desoxidante e melhora a fluidez e a fundibilidade da liga; o nióbio, além de formar carbetos também forma óxidos superficiais e assim controla a formação de óxidos de cromo, o que em quantidade excessiva diminuirá a adesão da porcelana, em se tratando de ligas indicadas para peças estéticas.

São inúmeras as ligas do sistema $\mathrm{Ni} / \mathrm{Cr}$ comercializadas atualmente, porém contêm diferenças composicionais que modificam suas propriedades físicas e químicas e alteram suas características quando da manipulação laboratorial (BARAN, 1983). A ausência de metais preciosos levou as ligas de metais básicos a uma maior propensão em sofrer corrosão e manchamento no meio bucal. Porém, devido à própria presença do cromo e do cobalto, as ligas de $\mathrm{Ni} / \mathrm{Cr}$ passaram a ter um comportamento mecânico superior às ligas áureas, o que as tornou ligas de escolha para a confecção de metalocerâmicas (MEYER et al., 1979). 
Moffa et al. (1973) avaliaram algumas propriedades físicas de duas diferentes ligas de $\mathrm{Ni} / \mathrm{Cr}$ e de uma liga nobre à base de ouro. Testes mecânicos realizados em corpos-de-prova, no estado bruto de fusão revelaram que o módulo de elasticidade, o limite de escoamento e a dureza Vickers das ligas básicas superaram em 2 a 2,5 vezes os valores obtidos para a liga áurea; a porcentagem de alongamento, no entanto, foi três vezes menor. Outros corpos-de-prova foram submetidos a ciclos térmicos a fim de simular a aplicação e cocção da faceta estética de porcelana. Após o tratamento térmico, os autores avaliaram, novamente, a dureza superficial e verificaram que para as duas ligas de Ni/Cr o valor diminuiu de 256 e 352 VHN para 310 e 270 VHN, respectivamente, e para a liga nobre aumentou de 140 para 170 VHN, porém esta propriedade manteve-se inferior à das ligas básicas.

Moffa; Jenkins (1974) verificaram que houve uma alta variação nos valores de diferentes propriedades mecânicas e físicas entre 10 ligas de $\mathrm{Ni} / \mathrm{Cr}$ presentes no mercado. A resistência máxima à tração variou de 57 a $116 \mathrm{kgf} / \mathrm{mm}^{2}$; o limite de escoamento variou de 23 a $79.9 \mathrm{kgf} / \mathrm{mm}^{2}$; a porcentagem de alongamento valor de 3 a 33\%; a dureza Vickers foi duas vezes superior ao valor relativo às ligas áureas e a densidade volumétrica correspondeu à metade.

Morris (1989) comparou as propriedades mecânicas de 7 ligas metálicas indicadas para peças metalocerâmicas (uma de ouro/paládio - controle, três à base de paládio e três do sistema Ni/Cr). 
Realizou ensaios de tração e de dureza superficial, em espécimes na condição bruta de fusão e após a simulação da ciclagem térmica que ocorreu quando da aplicação da cerâmica. A comparação entre estas duas condições mostrou que a liga controle (Au-Pd) sofreu uma melhora nas propriedades mecânicas após o tratamento térmico, as ligas à base de paládio e as ligas à base de $\mathrm{Ni} / \mathrm{Cr}$ sofreram um decréscimo na dureza e um aumento no alongamento.

Huget et al. (1977) avaliaram a composição química, propriedades mecânicas e microestrutura de duas ligas comerciais de $\mathrm{Ni} / \mathrm{Cr}$ indicadas para restaurações e próteses fixas metalocerâmicas. Os ensaios foram realizados nas condições brutas de fusão e após ciclagem térmica própria da aplicação e cocção de facetas estéticas cerâmicas, sendo utilizados quatro ciclos. Os autores verificaram que, de acordo com a composição química da liga, podem ocorrer diferenças comportamentais entre estes dois estados, tendo em vista que uma das ligas apresentou maior homogeneidade da estrutura metalográfica, o que torna a liga mais dúctil e reduz o limite convencional de escoamento e o limite elástico. Em relação às propriedades mecânicas, em particular à dureza Rockwell 30N, verificaram que não houve diferenças estatisticamente significantes ao término do tratamento térmico.

Presswood et al. (1980), em extensa revisão de literatura a respeito das ligas de $\mathrm{Ni} / \mathrm{Cr}$ indicadas para restaurações 
metalocerâmicas, verificaram que estas ligas podem ser fundidas com precisão dimensional e não sofrem alterações dimensionais durante a cocção da porcelana; as fundições apresentaram lisura superficial e a aderência à porcelana foi tão satisfatória quanto a que ocorre com as ligas nobres e preciosas.

A maior parte dos elementos constituintes das ligas de metais não preciosos sofre alguma reação química durante o processo de fundição. As ligas de níquel, no estado líquido de fusão, são muito sensíveis ao carbono, formando-se os carbetos de zinco e carbetos de berílio. Todos os outros elementos nas ligas não preciosas são suscetíveis à formação de carbetos ou nitritos durante o processo de fundição. Assim sendo, a fonte de calor como acetileno é desaconselhável ser utilizada, por ser um tipo de chama que contamina altamente as ligas com produtos da combustão do carbono e também por ser uma chama de temperatura extremamente alta (MONDELLI, 1995).

Muitas vezes, a composição da liga requer aumento da temperatura de fusão ou um controle de temperatura mais preciso durante o procedimento de fusão. Dessa forma, a influência do processo de fundição, como o tipo de máquina de injeção da liga, a fonte de calor utilizada, sobre as propriedades das ligas odontológicas também deve ser considerado (MULDERS et al., 1996). 
A corrosão de uma liga é de central importância para o sucesso da prótese. Trata-se de um processo complexo em que é impossível predizer sua magnitude simplesmente com base na composição da liga. Em relação ao pH, a tendência dos metais e ligas odontológicas é de ter sua corrosão aumentada a medida que aumenta $\mathrm{opH}$, em função do aumento da dissolução dos metais (KEDICl et al., 1998). Segundo Bayramoglu et al. (2000), em pH mais elevados a corrente de

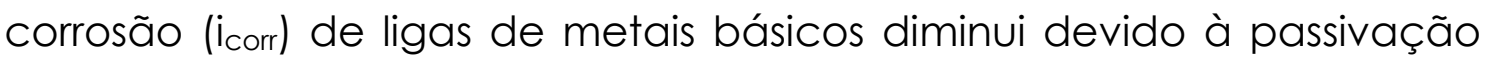
da liga. O mesmo não vale para as ligas nobres; a dissolução dos metais preciosos diminui com o aumento do $\mathrm{pH}$.

\section{4 - O titânio e suas ligas}

O titânio é um dos elementos mais abundantes encontrados na natureza. Na condição de metal, é semelhante ao aço inoxidável, pois apresenta densidade baixa, alta resistência à corrosão e ótima compatibilidade com os tecidos vivos (LAKHTIN, 1970; POLUKTHIN, 1970; LEE, 1971). É um excelente endurecedor, inclusive quando associado ao ouro (HANSEN; ANDERKO, 1958).

Por outro lado, apresenta alto ponto de fusão e grande reatividade química a altas temperaturas, devendo ser fundido no vácuo ou em atmosfera inerte, por exemplo, de argônio (LAKHTIN, 1970; POLUKTHIN, 1970; LEE, 1971). 
Como exemplo de suas aplicações, pode-se citar seu uso em ligas de alumínio e àquelas de Co/Cr (POLUKTHIN, 1970). Também hoje é largamente utilizado em aplicações navais e aeroespaciais. Sua propriedade especial, de excelente biocompatibilidade, tornou-o atrativo para a medicina e odontologia na confecção de partes de válvulas cardíacas, de implantes ortopédicos e de implantes odontológicos.

Adell et al. (1981) estudaram a osseointegração do implante de titânio, na forma de parafuso, em pacientes edêntulos. Durante um período de 15 anos (1965 - 1980), os autores realizaram 2768 implantes em 410 maxilares de 371 pacientes e sobre eles foram confeccionadas próteses reabilitadoras removíveis. Os resultados mostraram que no primeiro ano do uso da prótese houve perda de 1,5mm/ano de osso; após este período a perda foi de $1,0 \mathrm{~mm} /$ ano. Dentre os aspectos avaliados pelos autores, o titânio comportou-se de maneira compatível com o organismo dos pacientes e, assim, não provocou nenhuma resposta que fosse prejudicial ao paciente.

Ericsson et al. (1986) avaliaram estruturas de titânio para implantes em associação com próteses para pacientes parcialmente desdentados. Os implantes foram distribuídos segundo a necessidade de cada paciente, utilizando implantes do tipo Branemark. Os pacientes foram reavaliados nos períodos de 6 a 30 meses após a colocação dos implantes. Os autores observaram ótimos resultados clínicos, porém 
notaram algumas reações teciduais, podendo ser devido à liberação de alguns íons livres para o organismo dos pacientes, o que podem gerar certa sensibilidade ao metal. Mas, quando analisaram com maior critério, puderam observar que não ocorreram falhas estruturais do implante na presença do titânio, podendo ser devido ao pequeno tempo de observação e pelo pequeno número de pacientes estudados.

O titânio é um metal muito reativo, mas a camada de óxido que se forma instantânea e espontaneamente sobre sua superfície no ar, transforma essa mesma superfície metálica de uma condição ativa para outra passiva. $O$ filme de óxido é bastante protetor contra o ataque de químicos. Entretanto, soluções ácidas, ambientes muito oxidantes e a presença de íons fluoreto diminuem a qualidade protetora de filme de óxido e pode ocorrer a corrosão (STRIETZEL et al., 1998).

A incorporação de titânio nas ligas de $\mathrm{Ni} / \mathrm{Cr}$ participa na formação da fase $Y^{\prime}\left(\mathrm{Ni}_{3} \mathrm{~A} I \mathrm{Ti}\right)$, responsável por maior resistência mecânica e dureza. Vários estudos sobre a corrosão do titânio demonstram o seu comportamento muito favorável, porém quando se utiliza o titânio como material restaurador, deve-se observar que ele pode ser um condutor, quando em contato com outros materiais metálicos. Se o titânio é o membro catódico do par galvânico, pode acelerar a corrosão do outro metal. 
A resistência à corrosão do titânio é altamente dependente da estabilidade da camada de óxido superficial presente. A presença de íons flúor reduz essa camada protetora. Isso ocorre devido à formação de moléculas complexas de titânio-fluoreto que são muito estáveis e solúveis em soluções eletrolíticas (RECLARU; MEYER, 1998). Com um pH 6-7 são suficientes apenas 20 ppm de fluoreto para produzir uma maior corrosão na área.

Ao longo do tempo, têm surgido inúmeras propostas de formulações ou mesmo alterações de composição de ligas metálicas para uso odontológico. São ligas cujas composições básicas envolvem os mais diferentes metais: cobalto, cromo, cobre, alumínio, manganês, zinco, paládio, titânio (MATTOS et al., 1993; BEZZON et al., 1995).

Hruska; Borelli (1991) realizaram experimentos com titânio e com liga de titânio (Ti6Al4Va) quanto aos processos de fundição, soldagem laboratorial e teste de corrosão. Devido à característica de formar uma camada de óxido aderente quando na presença de ar, os resultados obtidos no estudo demonstraram que tanto o titânio como as suas ligas podem ser utilizadas para as restaurações protéticas e também para implantes, por ser um material biocompatível e resistente à corrosão, comparado a outros metais nobres e não-nobres.

Lautenschlager; Monaghan (1993), em uma revisão de literatura, compararam o uso do titânio comercialmente puro (Ti cp) e de ligas 
de titânio para uso em Odontologia com base em vários critérios como baixo peso, alta resistência às cargas, baixo módulo de elasticidade e resistência à corrosão. Segundo os autores, pesquisas devem ser realizadas para permitir o aprimoramento da utilização dessas ligas, como na obtenção de estruturas metálicas de próteses parciais. Entretanto, os resultados em longo prazo de peças protéticas obtidas em titânio por fundição encontrados por Wang; Fenton (1996) demonstraram perda de união entre a porcelana e a estrutura de titânio. Os autores concluíram que esta substituição de ligas nãonobres por titânio deverá ser um processo lento.

Devido ao aumento do reconhecimento de que, em longo prazo, a recolocação de articulação pode estar associada a reações adversas locais e sistêmicas que são mediadas pela degradação de produtos provenientes do material protético, Jacobs et al. (1998) mediram a concentração de titânio, alumínio, cobalto e cromo no soro e a concentração de cromo na urina de 75 pacientes durante três anos pós-operatórios, em um estudo longitudinal. Vinte pacientes que não tinham implantes foram considerados controle. Os resultados do estudo demonstraram que, após 36 meses pós-operatórios, os pacientes que tiveram um bom funcionamento da prótese com componentes que continham titânio tiveram apresentaram uma concentração de titânio no soro três vezes maior, enquanto que aqueles pacientes que tinham próteses com ligas de cobalto apresentaram um aumento de cinco a 
oito vezes maior dos componentes da liga no soro e na urina, respectivamente.

Investigações eletroquímicas in vitro tem sido uma ferramenta muito útil para se conhecer a corrosão dos materiais dentários metálicos e comparar sua estabilidade no ambiente da cavidade oral. Conseqüentemente, é necessário um equilíbrio dos testes in vitro com a realidade do ambiente bucal, para que se consiga obter resultados similares à condição clínica (STRIETZEL et al., 1998).

Para Neville; McDougall (2001) pouca atenção tem sido dada à degradação mecânica ocorrida após a corrosão.

O ambiente bucal é complexo. A saliva é composta de uma série de compostos orgânicos e inorgânicos. Além disso, sua composição é única e é influenciada por um grande número de variáveis, incluindo a hora do dia, a dieta e as condições físicas do indivíduo. Dessa forma, segundo Ledvina; Rigney (1998), usar a saliva natural como eletrólito para testes tem muitas limitações.

Cabrini et al. (1997), optaram por utilizar solução fisiológica para verificar a corrente de corrosão de uma liga de Ti6Al4V.

Schiff et al. (2002) avaliaram a influência do flúor e do pH da saliva artificial na resistência à corrosão de liga de titânio e de outras ligas comumente utilizadas na odontologia pelo aplicação de potencial corrosivo em soluções de saliva artificial de Fusayama e Meyer. Os 
resultados mostraram que a liga de titânio tem boa resistência à corrosão, porém as ligas de Ni/Ti e Ni/Ti/Co mostraram menor resistência.

Rondelli; Vicentini (1999) simularam a corrosão de ligas ortodônticas comerciais de Ni/Ti em fluidos humanos. As ligas a base de Co foram utilizadas como controle. O teste potenciodinâmico em saliva artificial a $40^{\circ} \mathrm{C}$ indicou uma suficiente resistência à corrosão destes fios, similares à resistência da liga de Co. O teste potenciodinâmico em salina $(0,9 \% \mathrm{NaCl})$ demonstrou-se baixo para as ligas de Ni/Ti na corrosão por picadas, na taxa de 200-400mV versus SCE, e as ligas de Co não sofreram com as picadas. Os autores afirmaram que a variação das condições da boca pode levar à corrosão desta superfície, além de detectar a liberação de uma quantidade de níquel desta liga.

Bayramoglu et al. (2000) estudaram o efeito do pH na corrosão de ligas e metais odontológicos, que tem diferentes composições. A taxa de corrosão e a curva de Tafel foram obtidas pela polarização anódica. Os efeitos do pH foram dependentes de sua composição. A dissolução foi menor para as ligas de titânio devido ao recobrimento da superfície por uma camada protetora e a máxima dissolução foi para as amostras com cobre e estanho. A adição de cobalto e molibdênio nas ligas aumentou a resistência à corrosão, não tendo diferença em relação ao pH. As características corrosivas do metal e da liga odontológica são importantes porque a tendência corrosiva destas ligas 
na cavidade bucal pode gerar problemas e perda posterior da restauração protética.

Turpin et al. (2000) determinaram a influência do ácido fluorídrico utilizado em cimentações de peças protéticas com cimento resinoso sobre o titânio. Os ensaios foram realizados em solução de Brugirard em pH 5,5. O titânio foi recoberto com cimentos e a resistência à polarização foi testada. Os resultados puderam concluir que o ácido fluorídrico diminuiu a resistência à corrosão do titânio.

Outros autores também verificaram a influência de cimentos na passivação do titânio (DEMIREL et al., 2003). Os autores desenvolveram experimentos eletrolíticos que associaram o titânio ao cimento dental. A resistência à polarização do titânio foi determinada pelo recobrimento deste metal por vários tipos de cimentos e a associação do titânio ao cimento de zinco e eugenol proporcionou boa resistência à corrosão. Porém, os cimentos com fluoretos, como o caso dos cimentos de ionômero de vidro e fosfato de zinco, aumentaram a susceptibilidade da liga à corrosão.

lijima et al. (2001) analisaram o comportamento corrosivo de ligas ortodônticas comerciais de Ni/Ti e o polimento com duas soluções: $0,9 \% \mathrm{NaCl}$ e $1 \%$ de ácido lático. As ligas foram analisadas por técnicas eletroquímicas e liberação de íons. $O$ efeito do polimento da liga foi observado por ensaios de corrosão. A análise demonstrou a presença 
de uma camada de óxido composto por $\mathrm{TiO}_{2}$ com rastro de $\mathrm{Ni}$, que pode ter sido formado na superfície durante o seu tratamento e posterior processo de limpeza. A camada de óxido contribuiu para a alta resistência das ligas de $\mathrm{Ni} / \mathrm{Ti}$ em solução de $\mathrm{NaCl}$, entretanto esta camada não foi muito estável quando a solução utilizada era a solução de ácido lático.

Koike; Fujii (2001) avaliaram o comportamento corrosivo do Ti cp nas variações de pHs. As amostras de Ti cp foram imersas em 128mmol/l de ácido lático e fórmico de pHs 1 - 8,5 por três semanas a $37^{\circ} \mathrm{C}$. Foram observados solubilidade, cor, peso e estabilidade química. A quantidade de titânio dissolvido foi diminuindo conforme aumentava o pH. Além disso, os autores constataram uma maior variação de cor para os pHs de 2,5 a 4,0, além de menor peso das amostras em solução de ácido lático, não afetando o pH. Foi observado $\mathrm{TiO}_{2}$ correspondente a uma camada de filme de proteção nas amostras de titânio. Os resultados mostraram que as propriedades corrosivas do titânio estão dependentes do pH envolvido, podendo ser dissolvido em pHs de 1 a 8,5 em meios ácidos.

A presença de pequenas correntes elétricas na cavidade oral é fato muito conhecido (Schriever e Diamond, 1952; Matono e Fusayama, 1972; Darvell, 1978; Espevik, 1978; Johansson, Lemons et al., 1989; Reclaru e Meyer, 1995; Chern Lin, Lo et al., 1996; Kedici, Aksut et al., 1998; Patro, Singh et al., 1998; Grosgogeat, Reclaru et al., 1999; Bayramoglu, 
Alemdaroglu et al., 2000; Benatti, Miranda et al., 2000; lijima, Endo et al., 2001; Schiff, Grosgogeat et al., 2002; Demirel, Saygili et al., 2003; Garhammer, Hiller et al., 2004). Dentre estes, o trabalho de Schriever; Diamond (1952) é de muita importância na compreensão das correntes galvânicas e seu comportamento na cavidade oral.

Reclaru; Meyer (1994) analisaram a associação do titânio para implante com ligas odontológicas em uma célula galvânica. A saliva artificial foi o meio eletrolítico eleito para estes estudos. Várias associações de ligas com titânio foram realizadas e os parâmetros avaliados foram $\mathrm{E}_{\text {commom, }} \mathrm{E}_{\text {couple corr, }} \mathrm{E}_{\text {crevice, }} \mathrm{i}_{\text {corr, }} \mathrm{i}_{\text {couple corr }}$ e a curva de Tafel. De acordo com os resultados obtidos, as correntes medidas foram de mesma magnitude e as ligas preciosas foram as mais resistentes à corrosão, seguidas pelas ligas de titânio.

Chern Lin et al. (1996) estudaram a resistência à corrosão de três ligas de Ni/Ti, contendo 18, 25 e 28,4\% em peso de níquel em solução fisiológica de Hank's. Os resultados indicaram que Tia e $\mathrm{Ti}_{2} \mathrm{Ni}$ eram as duas maiores fases em todas as três ligas estudadas. A média relativa de $\mathrm{Ti}_{2} \mathrm{Ni}$ e a dureza da liga aumentaram com o aumento do conteúdo de níquel. Quanto à corrosão, as três ligas apresentaram comportamento corrosivo parecidos quando da polarização em solução de Hank's, em temperaturas constantes de $37^{\circ} \mathrm{C}$, apresentando corrente anódica crítica perto de $30 \mu \mathrm{A} / \mathrm{cm}^{2}$ e o potencial de quebra de filme passivo foi em torno de $1100 \mathrm{mV}$. 
Cai et al. (1999) estudaram o Ti cp com diferentes condições de superfície utilizando a técnica de polarização anódica e teste de imersão. As superfícies das amostras foram divididas em três grupos: (i) superfícies que receberam jateamento tendo uma cmada reativa; (ii) polimento da superfície sem a camada reativa; e (iii) superfícies que receberam jateamento sem a camada reativa. Duas soluções foram utilizadas para o ensaio: saliva artificial e solução salina ácida $(0,1 \mathrm{M}$ de ácido lático/0,1M de $\mathrm{NaCl}$ - pH=2). A polarização anódica teve início com $50 \mathrm{mV}$ e caminhou até o potencial de $+2250 \mathrm{mV}$ versus o eletrodo de prata (Ag/AgCl). As amostras (i) e (ii) foram também examinadas em teste de imersão onde permaneceram por seis meses em uma temperatura de $37^{\circ} \mathrm{C}$. Após os ensaios, as soluções foram submetidas à análise por absorção atômica para verificar a dissolução do titânio. Os resultados demonstraram que a passivação teve início em torno de $+1300 \mathrm{mV}$ para os três grupos, mas a densidade de corrente para o grupo jateado com a camada reativa foi maior. Os autores sugerem que a rugosidade e a presença de superfície reativa afetam a dissolução do Ti cp.

Paschoal et al. (2003) avaliaram o processo de corrosão do titânio puro, da liga Ti6Al4V, ligas de Co/Cr/Mo dentre outras. Foram realizados testes de polarização em solução fisiológica e os autores verificaram que as ligas à base de titânio comportaram-se melhor que as demais, apresentando boa resistência à corrosão. 
Monacci (2000) avaliou densidade volumétrica, fundibilidade, dureza superficial Rockwell 15T, tipos de padrão de cristalinidade, composição química (quantitativa e qualitativa) e microestrutura de quatro ligas à base de níquel contendo porcentagens diferentes de titânio (1, 3, 2,4 e 2,5\%) para uso odontológico. Quanto às propriedades físicas, os resultados mostraram que não houve diferenças estatisticamente significantes quanto à densidade e fundibilidade das diferentes ligas. Em relação à dureza, as ligas com 2,4 e 3\% de titânio apresentaram maior dureza superficial com diferenças estatisticamente significantes em relação às demais.

Galo (2004) avaliou a resistência à corrosão de ligas odontológicas convencionais e as ligas com titânio, imersas em solução de saliva artificial, fundidas segundo dois processos de fundição: por plasma e por indução. Para isso, foram utilizadas ligas de Co/Cr, Co/Cr/Mo/W, Ni/Cr/Be, Ni/Cr, Ni/Cr/Ti, Liga de titânio (Ti6Al4V) e Ti cp. Os resultados indicaram haver diferenças estatisticamente significantes entre os métodos de fundição e entre as ligas utilizadas, quanto à resistência à corrosão. As ligas fundidas por chama obtiveram melhores valores de resistência à corrosão, assim como as ligas que continham titânio tiveram comportamentos melhores. 
3. Proposição 


\section{Proposição}

O objetivo deste trabalho foi avaliar in vitro a resistência a corrosão e condição superficial de três ligas a base de $\mathrm{Ni} / \mathrm{Cr}$ com diferentes porcentagens de Ti utilizadas com finalidade odontológica. 
4. Escaterial e Escétodos 


\section{Material e Métodos}

Para o desenvolvimento desta pesquisa, foram utilizadas ligas à base de $\mathrm{Ni} / \mathrm{Cr}$ contendo porcentagens diferentes de titânio e uma liga comercial. As composições das ligas podem ser vista na Tabela 1.

Tabela 1 - Ligas utilizadas e suas composições

\begin{tabular}{|c|c|c|c|c|c|c|c|c|c|}
\hline \multirow{2}{*}{ Marca } & \multirow{2}{*}{ Fabricante } & \multicolumn{8}{|c|}{ Composição química diretriz (\%) } \\
\hline & & $\mathrm{Ni}$ & $\mathrm{Cr}$ & $\mathrm{Fe}$ & Mo & $\mathrm{Nb}$ & $\mathrm{Ti}$ & $\mathrm{Al}$ & Outros \\
\hline $\begin{array}{c}\text { VAT80A } \\
\text { (VAT) }\end{array}$ & Villares & Base & 20,0 & - & - & - & 2,4 & 1,3 & - \\
\hline $\begin{array}{c}\text { Inconel } \\
\text { X750 (INC) }\end{array}$ & $\begin{array}{c}\text { Metals do } \\
\text { Brasil }\end{array}$ & Base & 15,0 & 7,0 & - & 1,0 & 2,5 & 0,7 & - \\
\hline $\begin{array}{c}\text { Waspaloy } \\
\text { (WASP) }\end{array}$ & & Base & 20,0 & - & 4,3 & - & 3,0 & 1,3 & $\mathrm{Co}=14,0$ \\
\hline $\begin{array}{c}\text { Verabond II } \\
\text { (VERA) }\end{array}$ & $\begin{array}{c}\text { Aalba } \\
\text { Dent Inc }\end{array}$ & $\begin{array}{l}75,55 \\
\text { (máx) }\end{array}$ & 11,50 & & 3,50 & 4,25 & - & 2,25 & $\mathrm{Si}=3,50$ \\
\hline
\end{tabular}

\section{1 - Obtenção dos comos-de-prova}

Para a avaliação da resistência à corrosão das ligas experimentais, foram confeccionados 10 corpos-de-prova para cada liga estudada, na forma de uma pastilha, por meio da técnica da cera perdida. Para isso foi utilizada uma matriz metálica de aço inoxidável com interior perfeitamente liso, formada por duas partes encaixadas medindo 15 mm de diâmetro e 3mm de espessura (Fig 2 - A e B).
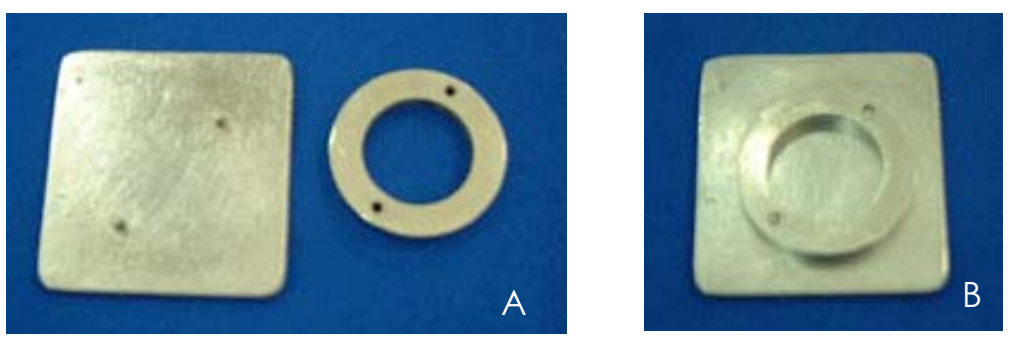

Figura 2 - Matriz metálica utilizada para obtenção dos copos-de-prova em cera. A) Matriz demontada; B) Matriz montada. 
A cera para fundição (Polidental - Cotia - SP - Brasil), previamente aquecida em um dispositivo elétrico termo regulável (Hotty Led - Renfert Gmbh, Hilzingen, Alemanha) e uma vez liquefeita, foi depositada no interior da matriz, de forma a ser totalmente preenchida sem defeitos e com ligeiro excesso. Após a solidificação completa, removeu-se o excesso de cera com o auxílio de uma espátula metálica lisa e limpa.

corpo-de-prova em cera foi liberado da matriz e foi colocado em algum ponto da superfície lateral do padrão de cera um bastão de cera para formar o canal de alimentação que foi encaixado no ápice de um conformador de cadinho e preso com cera. O conjunto pode ser visto na Fig 3.

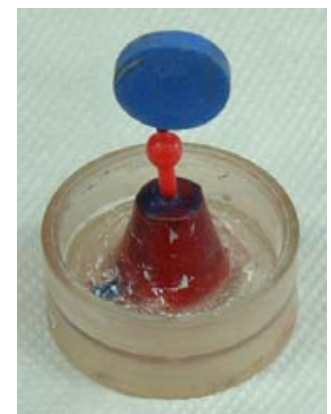

Figura 3 - Conjunto como-de-prova/cadinho

Em seguida, os padrões de cera foram incluídos em revestimento (Heat Shock - Polidental - Cotia - SP - Brasil). Após a presa do material, o conformador de cadinho e o anel de silicone foram removidos com cuidado, permanecendo o cilindro de revestimento para ser empregado na seqüência do processo. 
O bloco de revestimento foi colocado no interior de um forno (Forno EDG 1800 - EDG Equipamentos - São Carlos - SP - Brasil) préaquecido entre 750 e $850^{\circ} \mathrm{C}$. Aguardou-se 15 minutos a essa temperatura e em seguida o forno foi ajustado para a temperatura final de $950^{\circ} \mathrm{C}$, temperatura em que o anel permaneceu por 30 minutos, para completa distribuição de calor no cilindro.

A centrífuga elétrica (Powercast 1700 - EDG Equipamentos São Carlos - SP - Brasil) foi utilizada para injeção da liga líquida. O cadinho e dois botões de liga foram dispostos no aparelho e a fonte de calor aplicado para fusão das ligas foi um maçarico gás/oxigênio (Maçarico EDG - EDG Equipamentos - São Carlos - SP - Brasil).

Com o cilindro de revestimento posicionado na máquina de fundição, a centrifugação foi liberada para permitir a entrada do metal líquido no interior do revestimento promovendo o preenchimento do molde.

Para remoção do corpo-de-prova do interior do cilindro de revestimento, foi feita a imersão deste em água e, com um instrumento adequado, retirou-se o material refratário do corpo-de-prova metálico.

Após acabamento, o canal de alimentação foi removido, os corpos-de-prova foram jateados com alumina a $125 \mu \mathrm{m}$ e submetidos a ultra-som por 10 minutos em álcool isopropílico. 
As pastilhas (Fig. 4) foram incluídas em tubos de PVC preenchidos com resina acrílica quimicamente ativada (Clássico - São Paulo - SP - Brasil - Fig. 5).

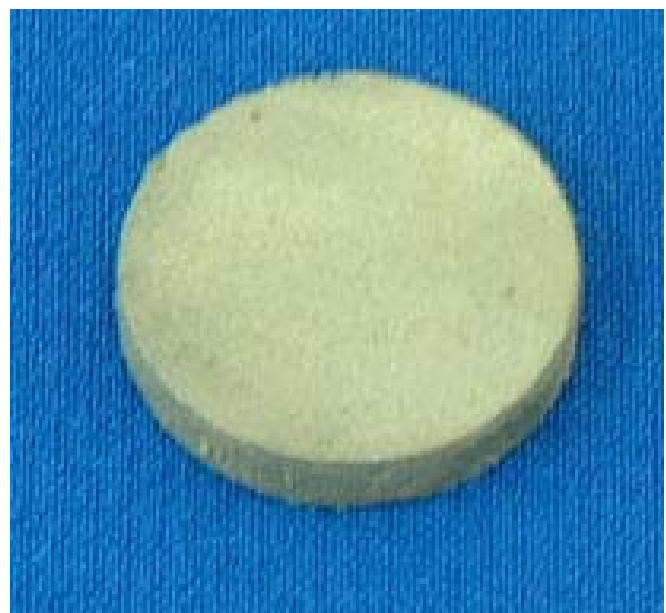

Figura 4 - Botão de liga após desinclusão e jateamento

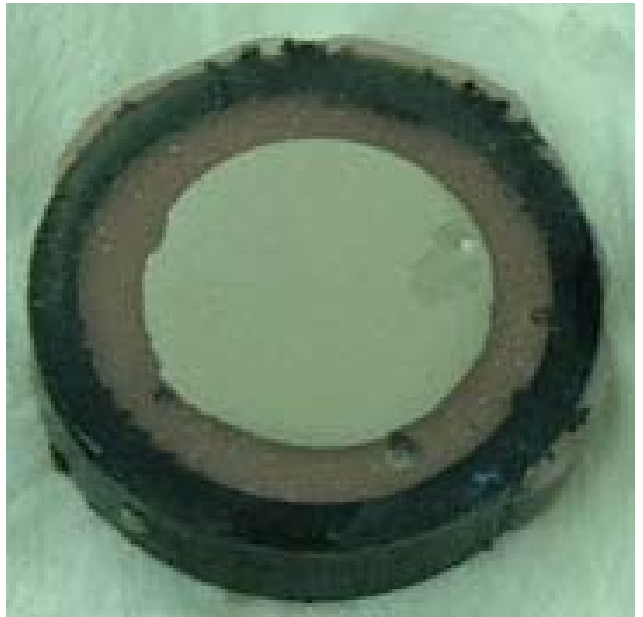

Figura 5 - Corpo-de-prova incluído em resina ac rilica

Na face em que foi analisado o comportamento corrosivo executou-se o polimento metalográfico como preconizado por Cai et al. (1999) em equipamento para polimento (Lixadeira e Politriz - Modelo PFL - FORTEL Ind e Com LTDA - São Paulo - SP) com lixas d'água (Norton - ABZ Fábrica de Lixas - Guarulhos - SP - Brasil), de granulação decrescente, com grãos de óxido de alumínio (80, 100, 320, 400, 600 e 800) e carbeto de silício (1000, 1200 e 2000).

Polimento foi finalizado com roda de pano e pasta de alumina de 1 1 m (AP-Paste - Struers - Ballerup - Denmark) de maneira que a pastilha apresentava aspecto final liso e brilhante.

Os corpos-de-prova polidos foram levados ao aparelho de ultra-som (Ultrassom 1440 D Comércio de Equipamentos Médico 
Odontológicos Ltda, Ribeirão Preto, SP, Brasil) imersos em álcool isopropílico para lavagem da superfície e remoção de qualquer resíduo de gordura. Em seguida, foram imersos em água destilada e novamente submetidos a ultra-som por 10 minutos. Após esse período, a superfície dos corpos-de-prova foi seca com auxílio de um jato de ar quente.

\section{2 - Resistência à comosão}

A célula eletrolítica (Fig. 6) é constituída por um recipiente de $500 \mathrm{~mL}$ e uma tampa de acrílico com orifícios. Nestes orifícios são encaixados os eletrodos de trabalho constituído pelo material a testar, o eletrodo de referência do tipo calomelano saturado e o eletrodo auxiliar de platina com $1 \mathrm{~cm}^{2}$ de área. $O$ sistema montado pode ser visto na (Fig. 7). A medição do potencial é efetuada a interface metal/solução.

Para verificação da resistência à corrosão das ligas foi utilizado - método de polarização anódica/potenciodinâmica em saliva artificial no equipamento VoltaLab - VM4 (Modelo PGP201, Radiometer Analytica - Copenhagen, Dinamarca - Fig 8a) acoplado ao software Voltamaster 4 (Fig 8b), fornecido pela mesma Empresa. 


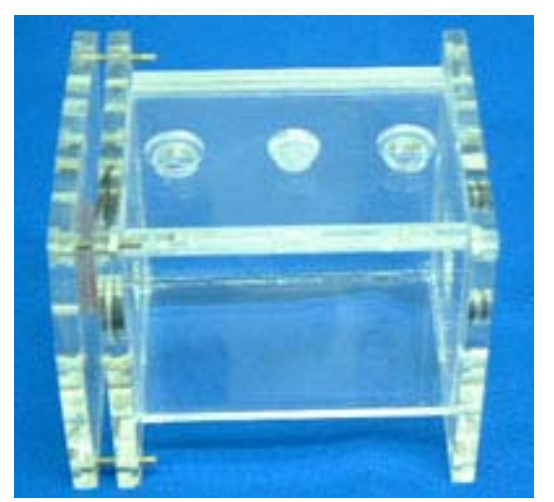

Figura 6 - Célula eletrolítica

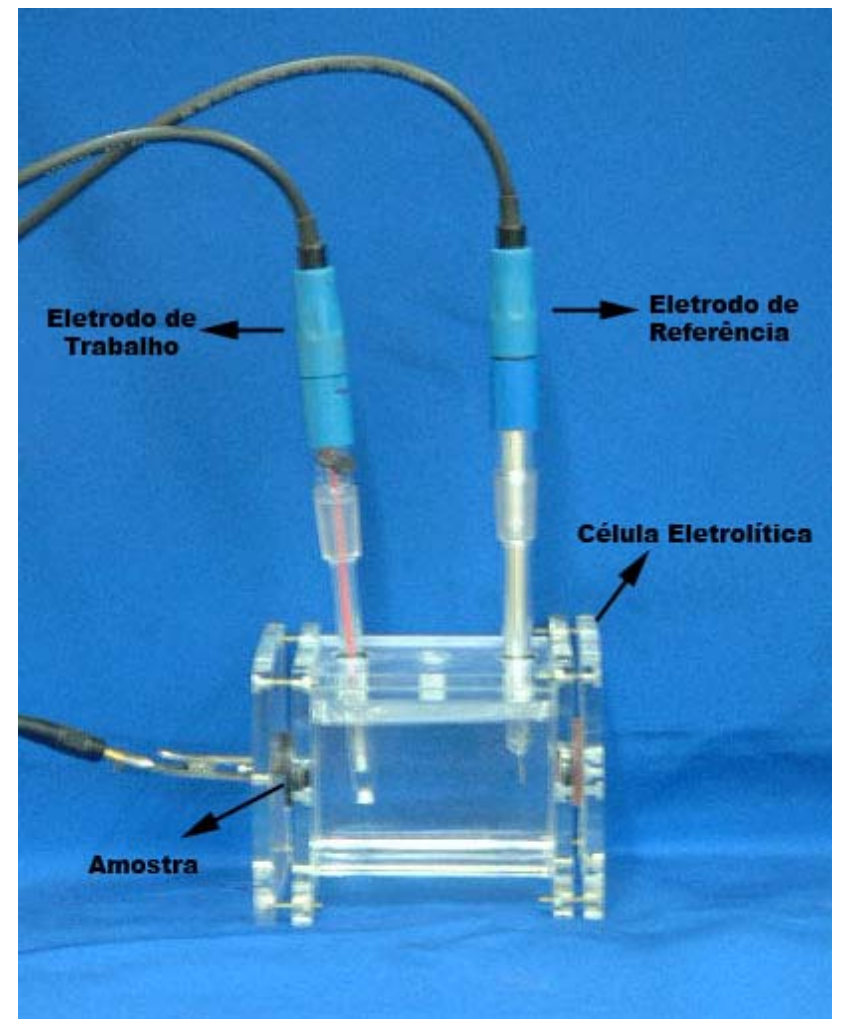

Figura 7 - Célula eletrolítica montada
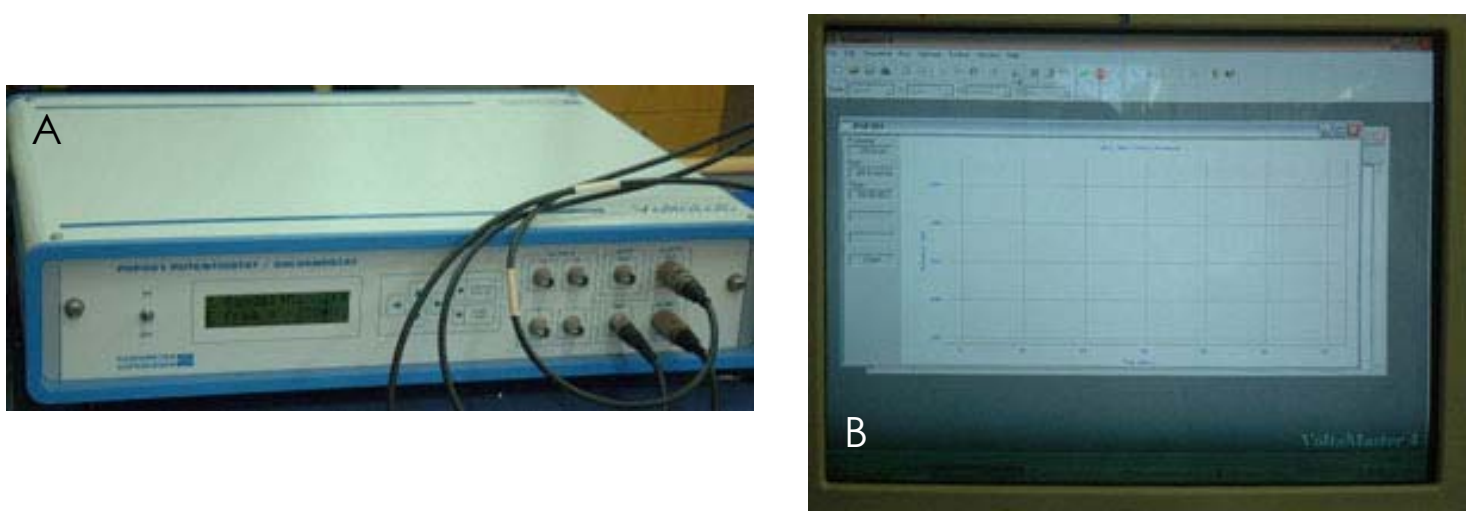

Figura 8 - A) Equipamento Voltalab utilizado para venificação da polanização anódica/potenc iodinâmica; B) $O$ equipamento Voltalab era acoplado a um mic rocomputadore os resultados eram capturados pelo Software VoltaMaster 
Para a análise de Potencial em Circuito Aberto (OCP), O período de mensuração foi de 60 minutos, com leitura do potencial a cada 30 segundos. Após os 60 minutos iniciava-se a Polarização Anódica em um potencial zero de $-500 m \vee$ terminando em um potencial um de $2000 \mathrm{mV}$, com leitura dos pontos a cada $120 \mathrm{mV} / \mathrm{min}$.

No momento da aplicação do ensaio, o software registra em arquivos separados, os dois parâmetros a serem estudados. Para a obtenção dos dados do Eocp, registra-se no gráfico formado (Fig 9) o potencial aos 60 minutos a partir de aumento sobre a imagem (Fig 10).

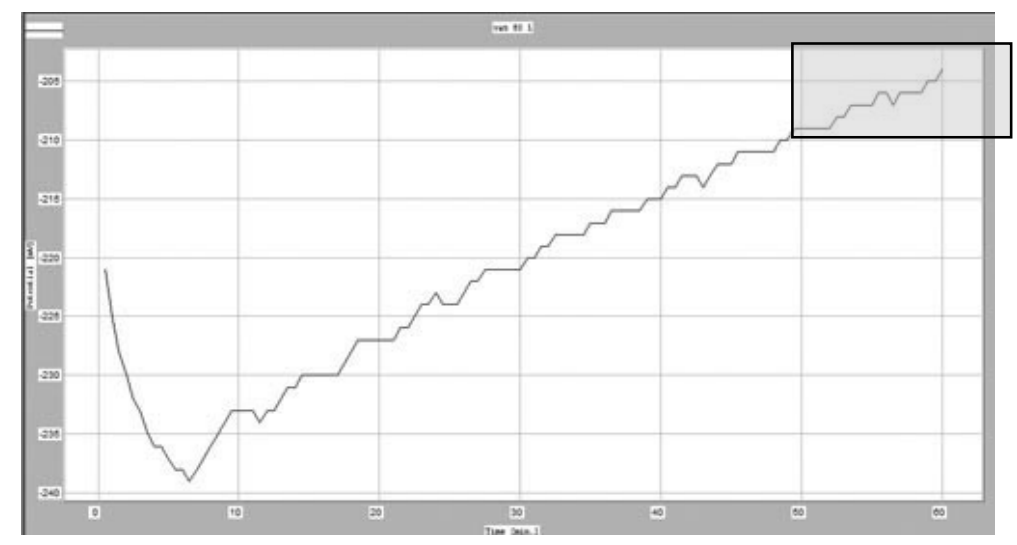

Figura 9- Gráfico Evs tempo. A área em destaque é a que deve ser ampliada para a venificação do valor de Eocp

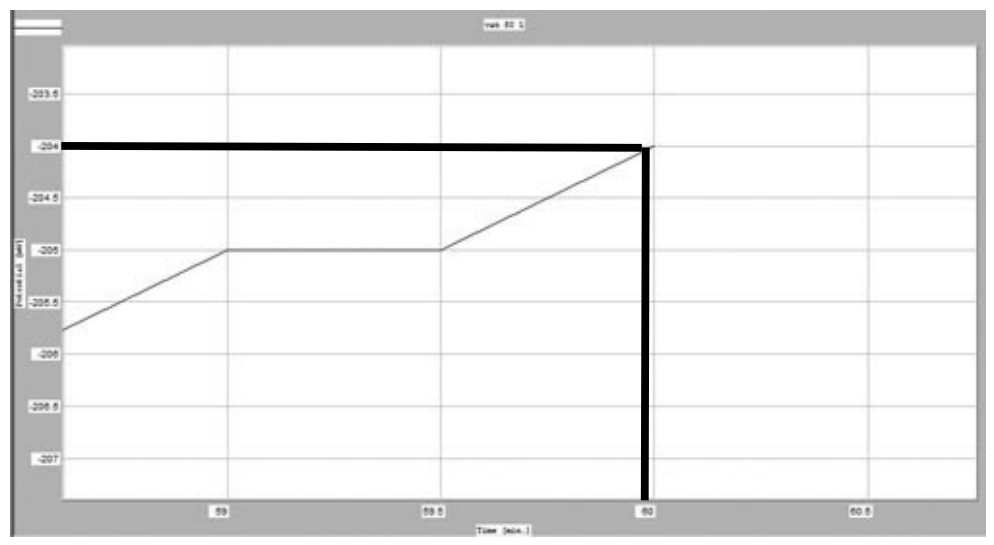

Figura 10 - Área do gráfico anterior aumentada. Em tempo de 60s, anota-se o valor de Eoc $p$ comespondente 
Para a obtenção dos dados da Polarização anódica, foram registrados os valores de potencial quando a corrente é igual a zero $\left(\mathrm{E}_{\mathrm{i}}=0\right)$ e da corrente de corrosão (i $\left.\mathrm{i}_{\text {corr }}\right)$. Para isso, a partir do gráfico formado no software obteve-se a Curva de Tafel utilizando, os seguintes parâmetros:

$$
\begin{aligned}
& \text { "Smoothing" =5 } \\
& \text { Zona de Cálculo }=200 \mathrm{mV} \\
& \text { Segmento }=50 \mathrm{mV}
\end{aligned}
$$

Seleciona-se a opção "Draw" (desenhar) e a curva é obtida, bem como os resultados para os parâmetros estudados (Fig. 11).

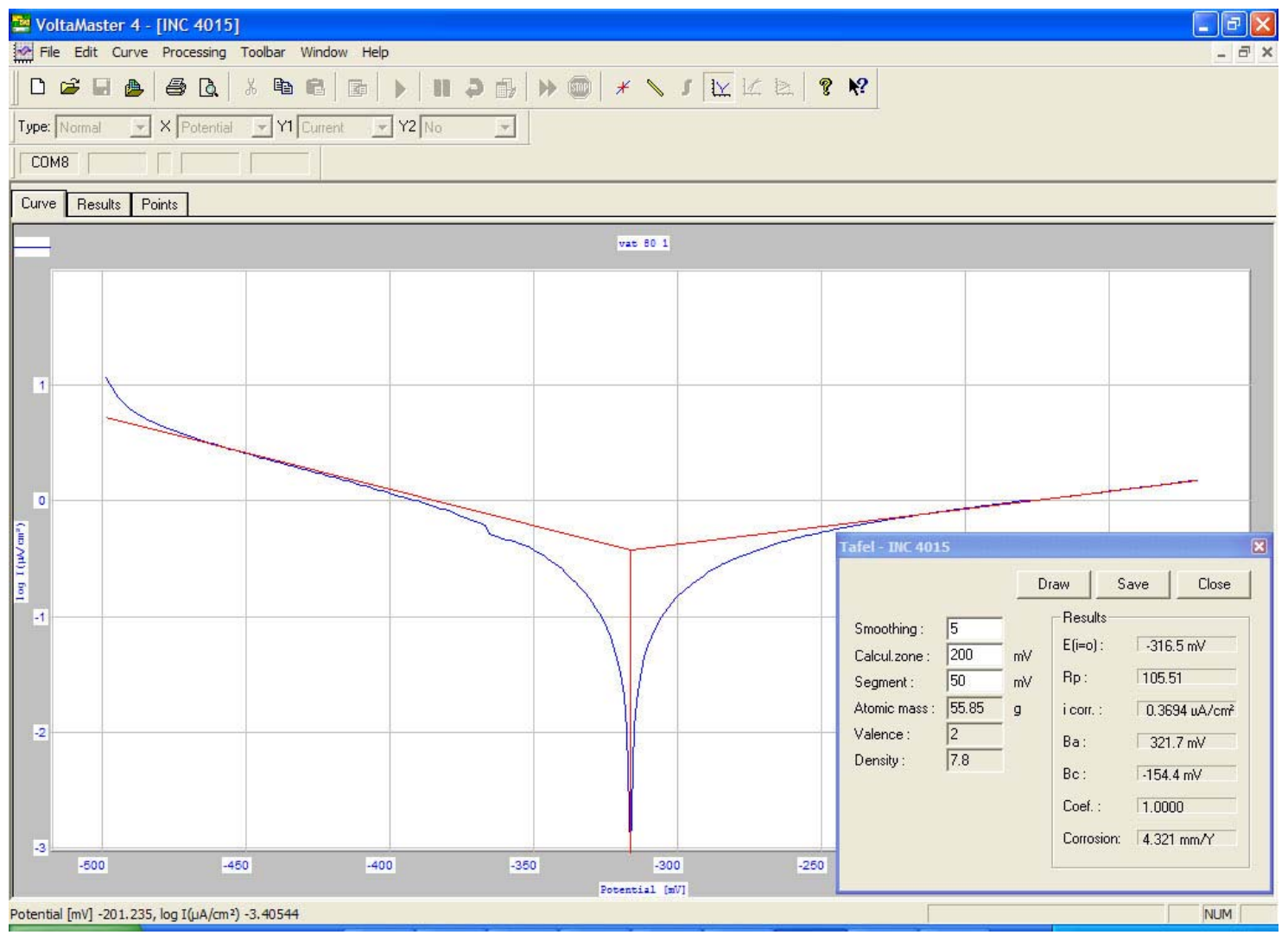

Figura 11 - Curva de Tafel construída para obtenção dos valores de $E_{(i=0)}$ e i corr 


\section{3 - Solução eletrolítica}

A solução eletrolítica utilizada foi saliva artificial em $\mathrm{pH}$ de 5,5 cuja composição pode ser vista na Tabela 2.

Tábela 2 - Composição da saliva artificial

\begin{tabular}{ll}
\hline \multicolumn{1}{c}{ Composto } & Porcentagem \\
\hline Fosfato de Potássio Monobásico & $0,036 \%$ \\
Fosfato de Potássio Bibásico anidro & $0,08 \%$ \\
Sorbitol 70\% & $4,27 \%$ \\
Cloreto de Potássio & $0,063 \%$ \\
Cloreto de Magnésio & $0,012 \%$ \\
Cloreto de Cálcio & $0,0072 \%$ \\
Cloreto de Sódio & $0,0863 \%$ \\
Sacarina Sódica & $0,03 \%$ \\
Conservante & $0,83 \%$ \\
Natrosol 225HHR & $0,1 \%$ \\
Água & q.s.p. \\
\hline
\end{tabular}

Para manter a solução a $37^{\circ} \mathrm{C}$ utilizou-se uma estufa com temperatura controlada (Fig. 12 e 13).

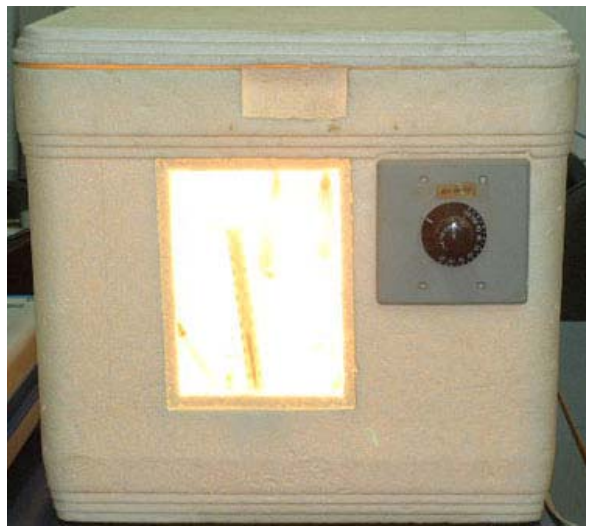

Figura 12 - Estufa utilizada para controle da temperatura em 379 C

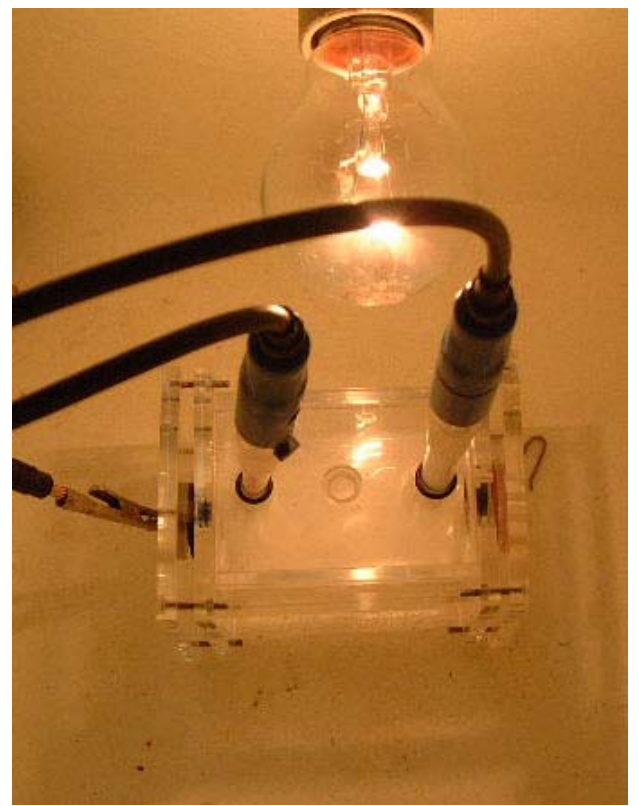

Figura 13 - Interior da estufa com temperatura controlada e a célula eletrolítica conectada aos eletrodos 


\section{4 - Análise da morfologia superficial}

Após as amostras serem submetidas à polarização anódica, submeteu-se um corpo-de-prova de cada grupo amostral à análise morfológica de sua superfície. Para isso, as amostras corroídas (Fig 14) foram examinadas em microscópio eletrônico de varredura (MEV - Jeol JSM 25 - SII, Sony, Tokyo, Japan) em três áreas representativas: na região que não sofreu a ação do eletrólito, na região corroída e na interface entre essas duas regiões.

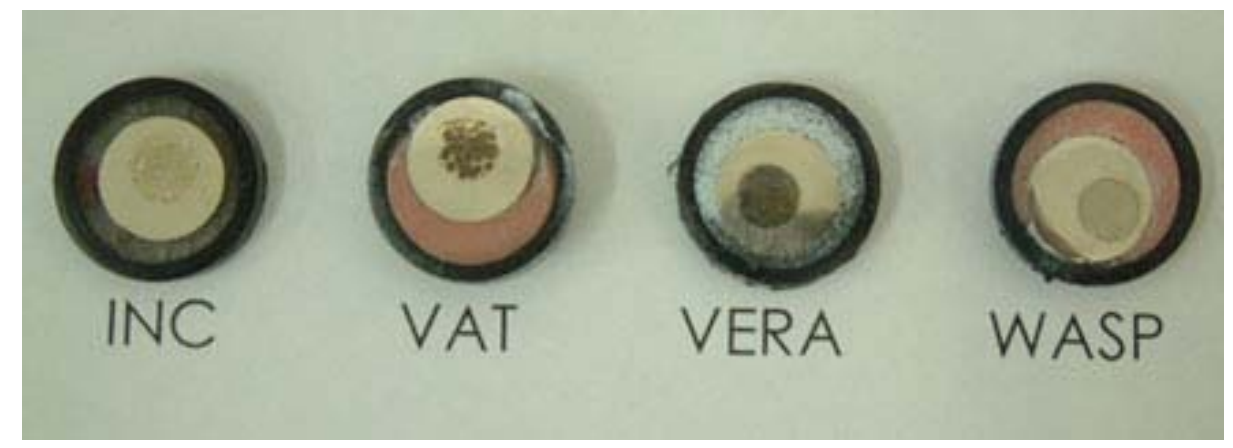

Figura 14 - Vista macroscópica das amostras após comosão

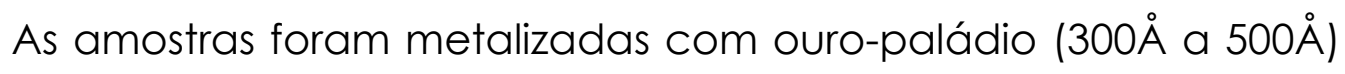
e posicionadas no MEV, operado em 15Kv. A análise das regiões sem e com corrosão foram analisados em aumento de 1500 vezes, enquanto a interface foi visualizada em aumento de 500 vezes. 
5. Resulfados 


\section{Resultados}

Para análise da corrosão das diferentes ligas foram analisadas as seguintes condições: potencial em circuito aberto (Eocp), potencial quando a corrente fosse igual a zero $\left(\mathrm{E}_{i}=0\right)$ e a corrente de corrosão (icorr).

\section{1 - Potencial em Circ uito Aberto (Eocp)}

Os valores do potencial em circuito aberto (Eocp), obtidos para cada liga estudada, podem ser vistos na Tabela 3.

Tabela 3 - Valores de Eocp para todas as amostras das ligas estudadas

\begin{tabular}{ccccc}
\hline Amostras & Ligas & INC & WASP & VERA \\
\hline 1 & -274 & -217 & -263 & -334 \\
2 & -222 & -276 & -294 & -265 \\
3 & -318 & -274 & -367 & -317 \\
4 & -271 & -216 & -338 & -319 \\
5 & -297 & -272 & -373 & -310 \\
6 & -262 & -233 & -223 & -339 \\
7 & -257 & -220 & -263 & -335 \\
8 & -332 & -246 & -63 & -308 \\
9 & -262 & -234 & -213 & -327 \\
10 & -241 & -204 & -249 & -313 \\
\hline
\end{tabular}

A análise preliminar dos resultados indicou tratar-se de uma distribuição amostral normal, permitindo a utilização de estatística paramétrica, pela análise de variância complementada pelo teste de Tukey com nível de significância de 95\%. A comparação das médias e os respectivos erros-padrão podem ser vistos na Tabela 4. 
Tabela 4 - Média (emo-padrão) de valores de Eocp

\begin{tabular}{ccccc}
\hline & VAT & INC & WASP & VERA \\
\hline Eocp & $-273,6(10,6)^{\mathrm{ab}}$ & $-239,2(8,4)^{\mathrm{a}}$ & $-264,6(28,6)^{\mathrm{ab}}$ & $-316,7(6,7)^{\mathrm{b}}$ \\
\hline
\end{tabular}

Letras diferentes indicam diferenças estatisticamente significantes $(p<0,05)$

A liga INC apresentou maior potencial médio, resultado estatisticamente significante em relação à liga VERA $(p<0,05)$ que apresentou menor potencial médio. As ligas VAT e WASP apresentaram valores médios de potencial intermediários sem significância estatística $(p>0,05)$ em relação às demais ligas estudadas.

A comparação das médias é mais visível graficamente, como é visto na Fig 15.

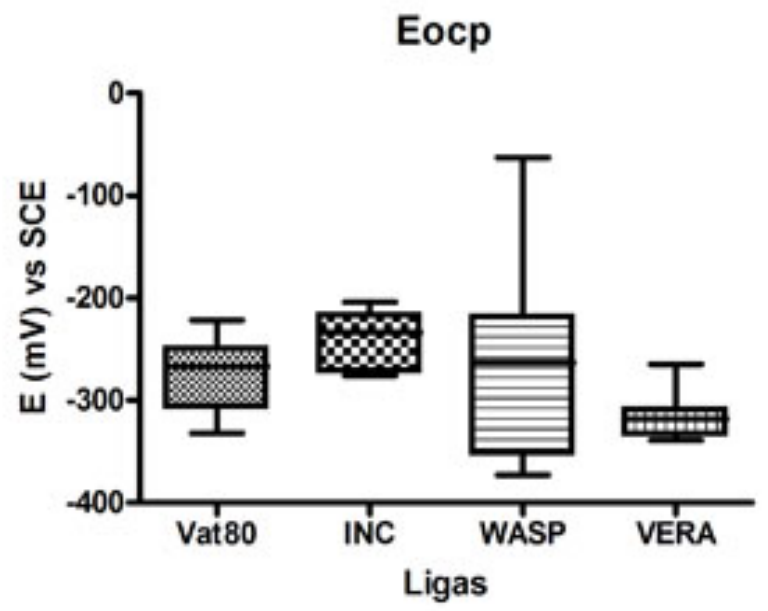

Figura 15 - Representação gráfica da comparação das médias das amostras de Eocp

O Gráfico da Fig. 16 permite visualizar o comportamento das ligas ao longo do período testado quando submetidas ao ensaio de 
OCP. As retas foram obtidas a partir da obtenção dos valores médios de potencial em cada 30 segundos para cada uma das amostras.

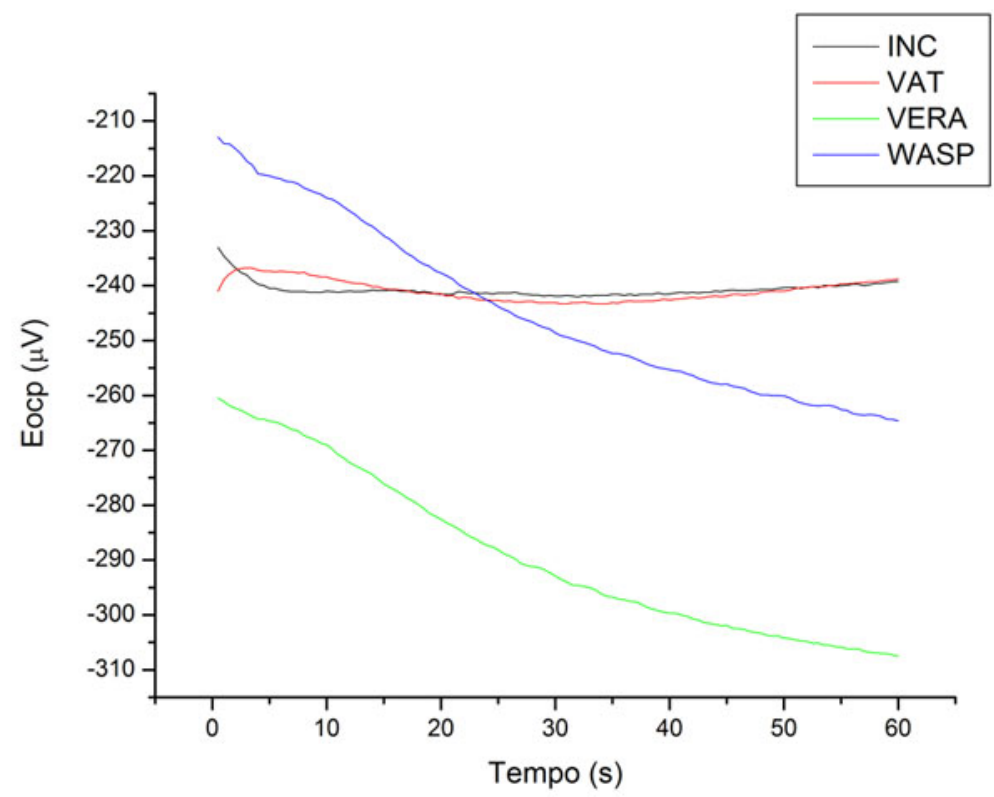

Figura 16 - Representação gráfica dos potenciais das ligas em c irc uito aberto (OCP) em relação ao tempo

Verifica-se pela análise das retas do gráfico que o comportamento das ligas VAT e INC foram semelhantes com potencial muito próximo (aproximadamente $-235 \mathrm{mV}$ ). Já nos primeiros momentos do teste houve a estabilização das ligas. As ligas VERA e WASP também apresentaram comportamentos semelhantes. Ao início do teste, a liga VERA apresentou valores médios de potencial de $-260 \mathrm{mV}$ e a WASP apresentou valores próximos a $-215 \mathrm{mV}$. Esses potenciais foram diminuindo à medida que o tempo aumentava. Verifica-se, assim, que a estabilização de íons com o meio foi difícil de ser conseguida. 


\section{2 - Potencial $\mathrm{E}=0$}

Os valores do potencial das ligas quando a corrente fosse igual a zero $\left(E_{i}=0\right)$, obtidos para cada liga estudada, podem ser vistos na Tabela 5.

Tabela 5 - Valores de potencial $(E=0)$ para todas as amostras das ligas estudadas

\begin{tabular}{|c|c|c|c|c|}
\hline Amostras Ligas & VAT & INC & WASP & VERA \\
\hline 1 & $-371,9$ & $-308,5$ & $-339,5$ & $-393,6$ \\
\hline 2 & -334 & $-363,6$ & $-319,6$ & $-349,5$ \\
\hline 3 & $-389,4$ & $-358,1$ & $-409,6$ & $-355,2$ \\
\hline 4 & $-373,4$ & $-316,5$ & $-396,3$ & $-391,9$ \\
\hline 5 & $-380,1$ & -336 & $-428,6$ & $-388,9$ \\
\hline 6 & $-389,3$ & $-361,1$ & $-342,2$ & $-417,2$ \\
\hline 7 & $-354,5$ & $-313,7$ & $-345,8$ & $-366,6$ \\
\hline 8 & $-371,9$ & $-341,4$ & $-158,7$ & $-364,6$ \\
\hline 9 & $-367,7$ & $-325,7$ & -298 & $-366,7$ \\
\hline 10 & $-386,4$ & $-311,7$ & $-353,6$ & $-380,8$ \\
\hline
\end{tabular}

A análise preliminar dos resultados indicou tratar-se de uma amostra com distribuição normal, permitindo a utilização de estatística paramétrica, pela análise de variância complementada pelo teste de Tukey com nível de significância de 95\%. A comparação das médias e os respectivos erros-padrão podem ser vistos na Tabela 6.

Tabela 6 - Média (emo-padrão) de valores de $\mathrm{E}=0$

\begin{tabular}{ccccc}
\hline & Vat80 & INC & WASP & VERA \\
\hline $\mathbf{E}=\mathbf{0}$ & $-371,9(5,42)^{a}$ & $-333,6(6,19)^{a}$ & $-339,2(23,8)^{a}$ & $-377,5(6,56)^{a}$ \\
\hline Letras semelhantes indicam que & não há & diferença & estatisticamente & significante \\
$(p<0,05)$ entre as médias & & & &
\end{tabular}

A análise das médias demonstrou que não houve diferença estatisticamente significante com nenhuma das ligas estudadas, ou seja, o comportamento delas, comparativamente, foram semelhantes. A comparação é mais visível graficamente (Fig. 17). 


\section{$\mathrm{Ei}=0$}

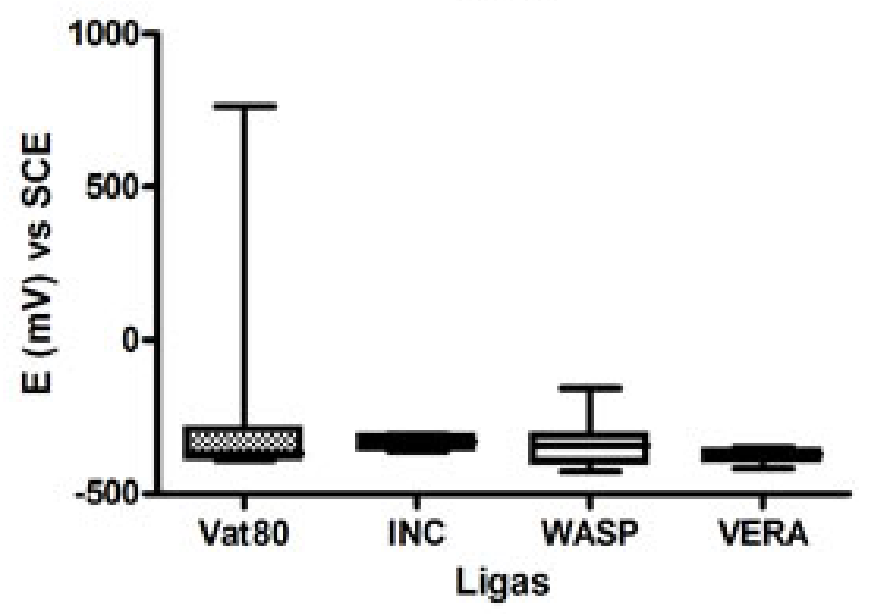

Figura 17 - Representação gráfica das médias de $E=0$

\section{3 - Comente de comosão (icor)}

Os valores de corrente de corrosão das ligas ( $\left.i_{\text {corr }}\right)$, obtidos para cada liga estudada, podem ser vistos na Tabela 7.

Tabela 7 - Valores de icor para todas as amostras das ligas estudadas

\begin{tabular}{|c|c|c|c|c|}
\hline Amostras Ligas & VAT & INC & WASP & VERA \\
\hline 1 & 0,2751 & 0,3362 & 0,8582 & 0,1063 \\
\hline 2 & 0,2633 & 0,0707 & 0,2044 & 0,0783 \\
\hline 3 & 0,0553 & 0,0684 & 0,0285 & 0,1708 \\
\hline 4 & 0,043 & 0,3043 & 0,0156 & 0,0457 \\
\hline 5 & 0,0842 & 0,2372 & 0,0433 & 0,0628 \\
\hline 6 & 0,1943 & 0,8468 & 0,5595 & 0,0371 \\
\hline 7 & 0,169 & 0,1924 & 0,5776 & 0,031 \\
\hline 8 & 0,1551 & 0,4686 & 1,4864 & 0,1196 \\
\hline 9 & 0,1124 & 0,3509 & 0,9132 & 0,1403 \\
\hline 10 & 0,1991 & 0,5659 & 0,3498 & 0,0896 \\
\hline
\end{tabular}

Para a análise estatística foram realizados os mesmos testes preliminares descritos para os dados dos ensaios anteriores, que indicou que a distribuição era normal, permitindo utilizar estatística paramétrica, pela análise de variância complementada pelo teste de 
Tukey com nível de significância de 95\%. A comparação das médias e os respectivos desvios-padrão podem ser vistos na Tabela 8.

Tábela 8 - Média (desvio-padrão) de valores de icor

\begin{tabular}{ccccc}
\hline & Vat80 & INC & WASP & VERA \\
\hline Icor & $0,1551(0,08)^{a}$ & $0,3441(0,24)^{a, b}$ & $0,5037(0,48)^{b}$ & $0,0881(0,05)^{a}$ \\
\hline
\end{tabular}
Letras diferentes indicam diferenças estatisticamente significantes $(p<0,05)$

A análise das médias demonstra que a menor corrente de corrosão ocorreu para a liga VERA, resultado estatisticamente significante em relação à liga WASP, que apresentou o maior valor de corrente, representando menor resistência à corrosão. Esse valor foi também diferente (estatisticamente significante) da liga VAT e a liga INC apresentou comportamento intermediário às demais ligas. A comparação é mais visível graficamente (Fig. 18).

\section{i corr}

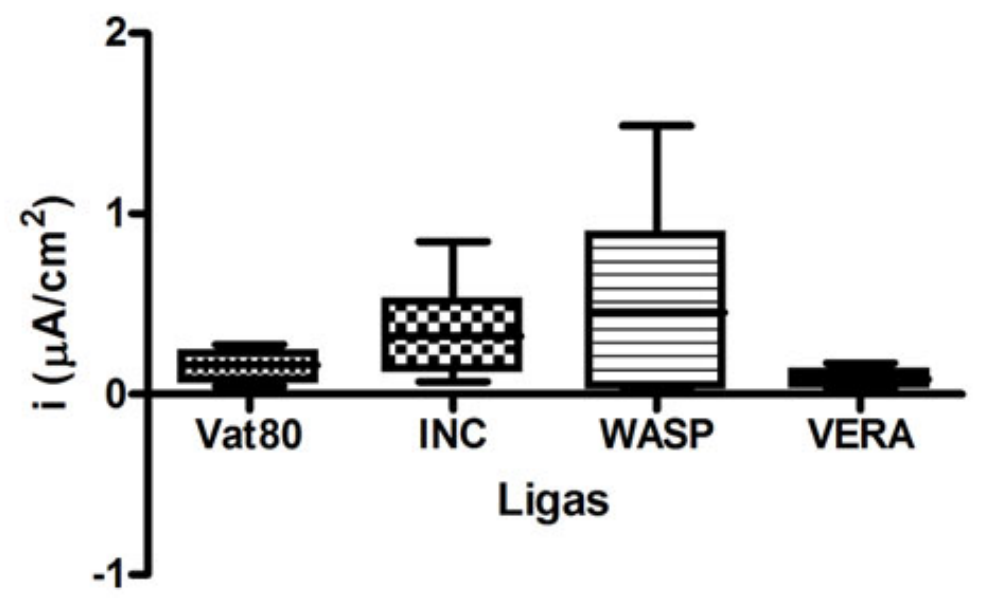

Figura 18 - Representação gráfica das médias de i̇cor

Uma melhor visualização da influência da polarização sobre a densidade de corrente é obtida através da representação gráfica de 
diagramas de potencial de eletrodo (E) versus densidade de corrente (i). As curvas que se obtêm são chamadas de curvas de polarização. Contudo, a equação de Tafel é de natureza logarítma (WOLYNEC, 2003), uma das maneiras de apresentar as curvas de polarização é em um diagrama $\mathrm{E}$ vs log $|\mathrm{i}|$.

O Gráfico da Fig. 19 permite visualizar a curva de polarização anódica das ligas. Para a obtenção desse gráfico, foram selecionados os dados da amostra que apresentavam os valores de $\mathrm{i}_{\text {corr }}$ mais próximos aos valores médios. A análise do gráfico deve ser feita de modo que, quanto mais paralela a curva está em relação ao potencial, mais estável é a liga. Isso quer dizer que em um ambiente, no caso a saliva artificial, a liga mantém seu comportamento. Quanto mais paralela a curva em relação ao eixo da corrente, maior corrosão irá ocorrer devido à instabilidade da curva em um mesmo potencial.

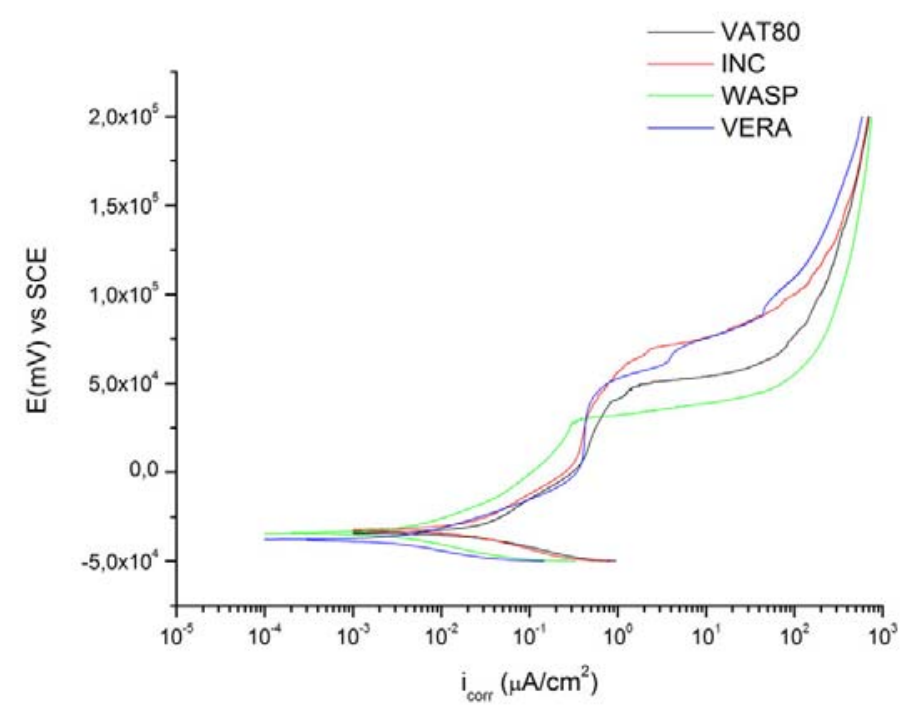

Figura 19 - Representação gráfica das curvas de polanização anódica das amostras 
A análise das retas permite verificar que os comportamentos das ligas INC, VERA e VAT foram muito semelhantes, de maneira que as linhas se apresentam quase sobrepostas. Próximo ao potencial zero essas ligas têm corrosão menos acentuada, sendo, em seguida, aumentada à medida que o potencial aumenta. A liga VAT apresenta uma maior corrosão que as outras duas. A liga WASP tem uma maior corrosão que as demais.

\section{4 - Análise morfológica superficial}

As fotomicrografias obtidas a partir do MEV podem ser vistas nas Fig. 20 a 23, respectivamente para as ligas VAT, INC, WASP e VERA.

As imagens revelam um comportamento muito heterogêneo das ligas frente à corrosão. As fotomicrografias revelam vários graus de rugosidade e porosidade na superfície das ligas. Verifica-se, de maneira muito clara, a diferença das superfícies corroídas e não corroídas.

A liga VAT apresentou uma superfície muito rugosa mesmo antes da corrosão e após o ensaio verificou-se um alto nível de corrosão, com formação de buracos na superfície corroída.

A liga INC apresentou uma superfície mais uniforme do que a liga VAT antes da corrosão. Após o ensaio, verificou-se que a superfície da liga ficou muito rugosa, indicando grande potencial corrosivo. 
As ligas WASP e VERA apresentaram comportamento muito semelhante de forma que, após a corrosão, é possível diferenciar as fases da liga. 


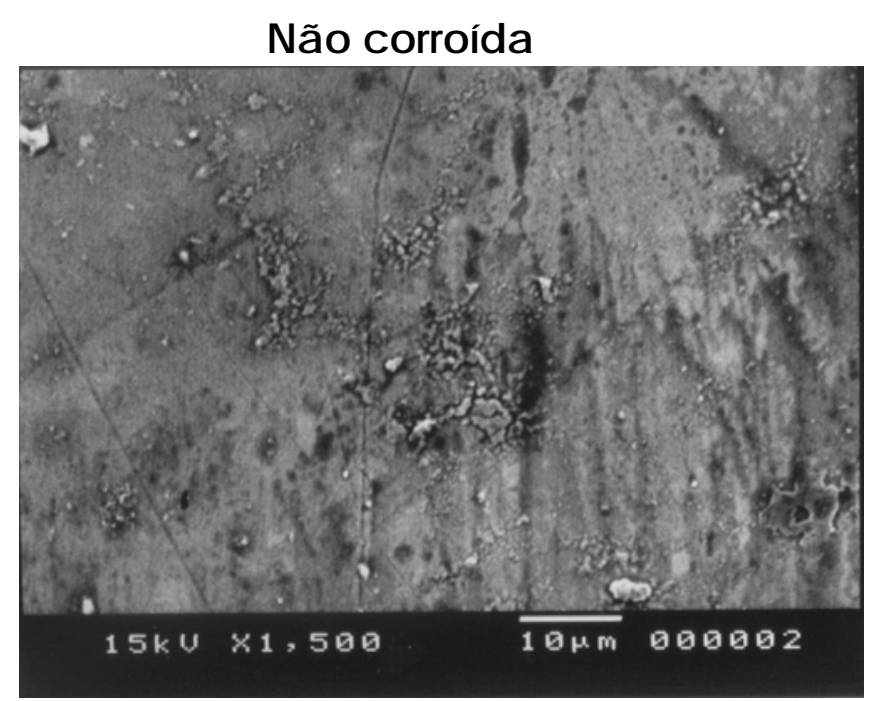

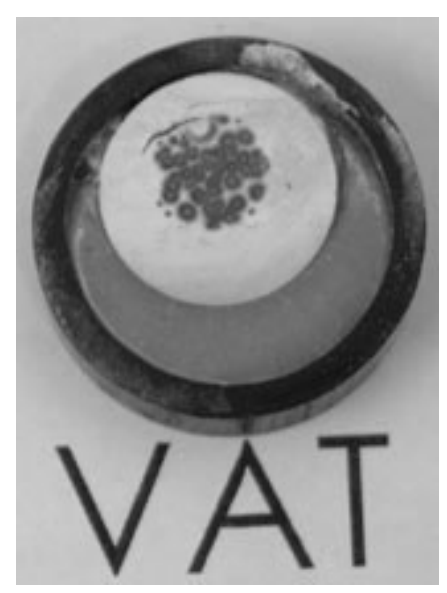

Interface
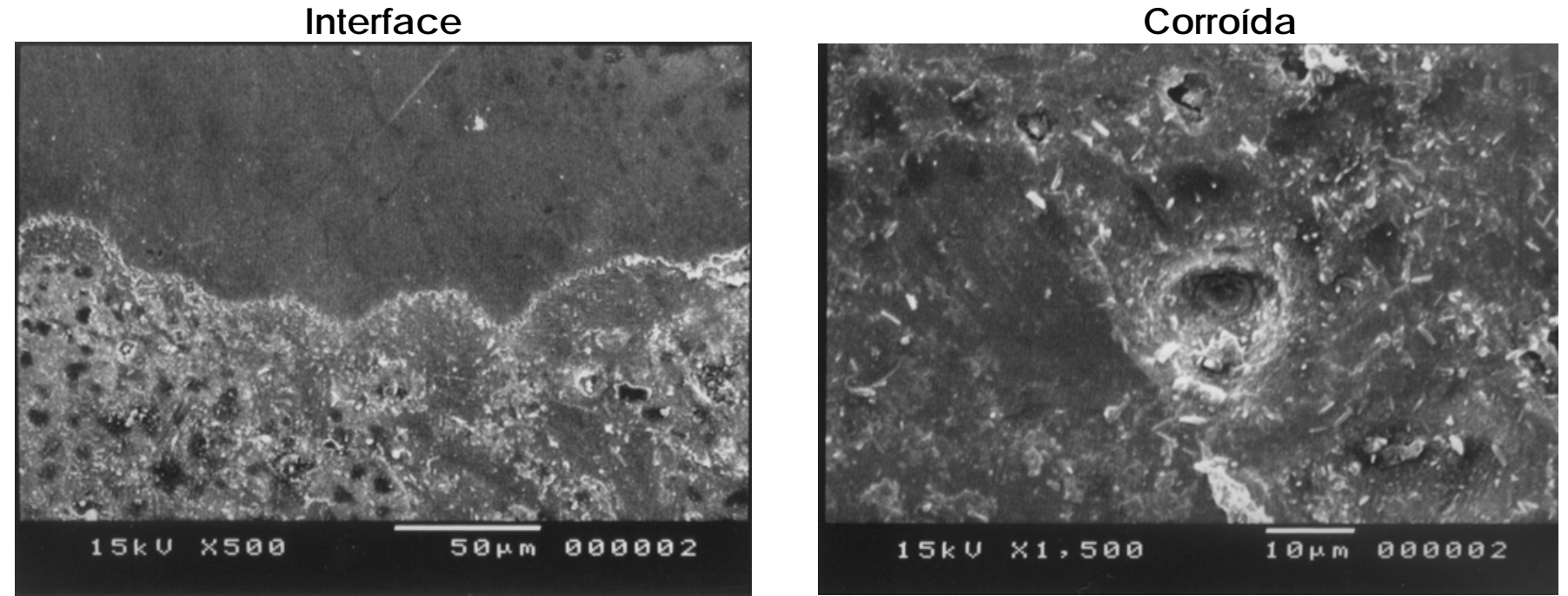

Figura 20 - Amostra após a comosão e fotomic rografias da liga VAT 


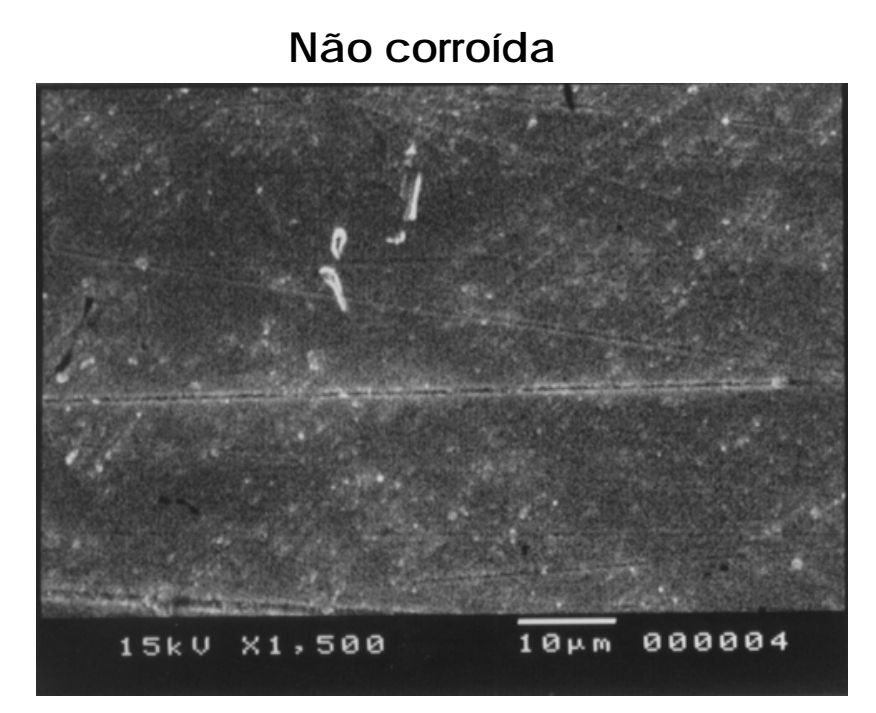

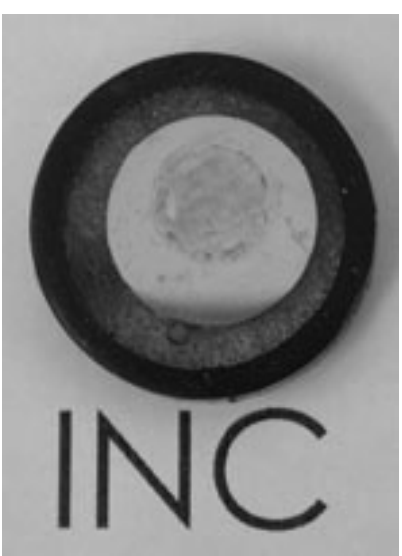

Interface
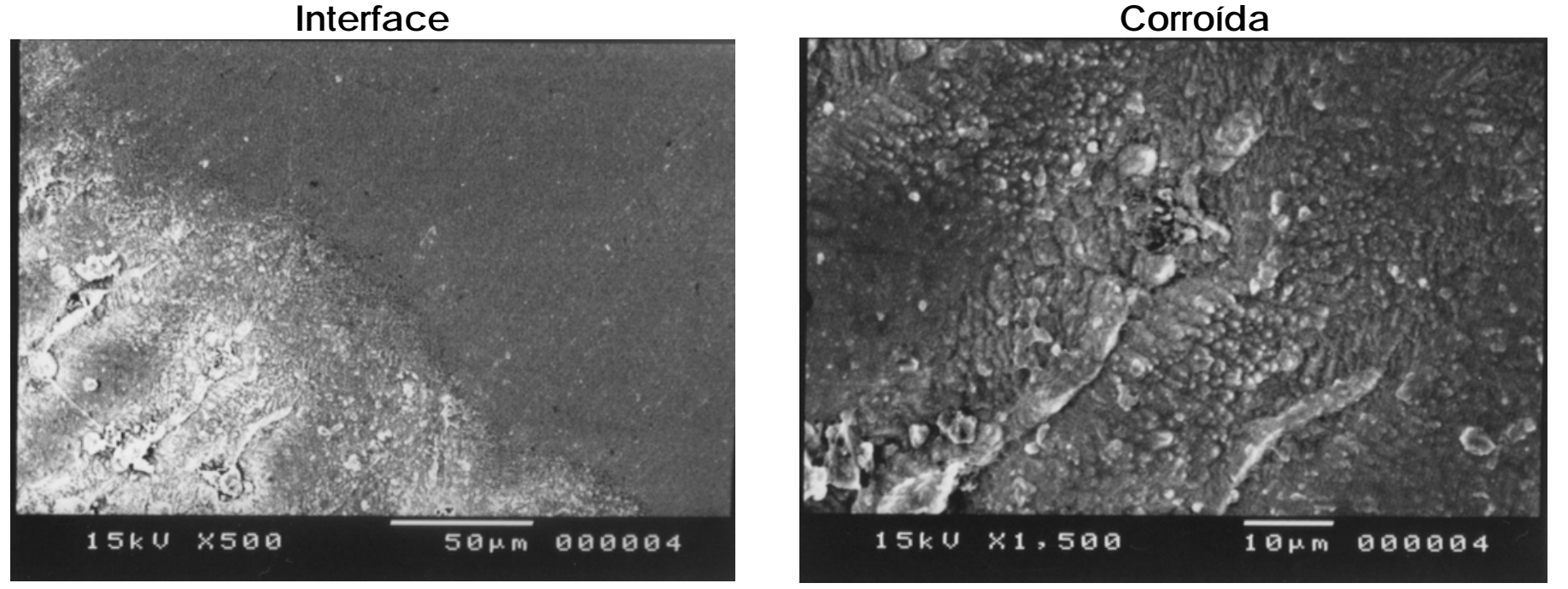

Figura 21 - Amostra após a comosão e fotomicrografias da liga INC 
Não comoída

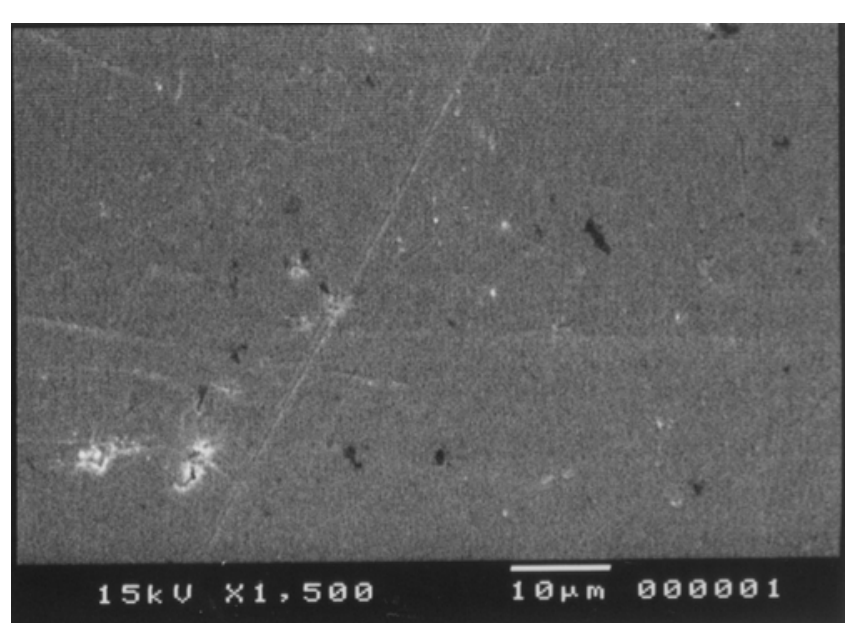

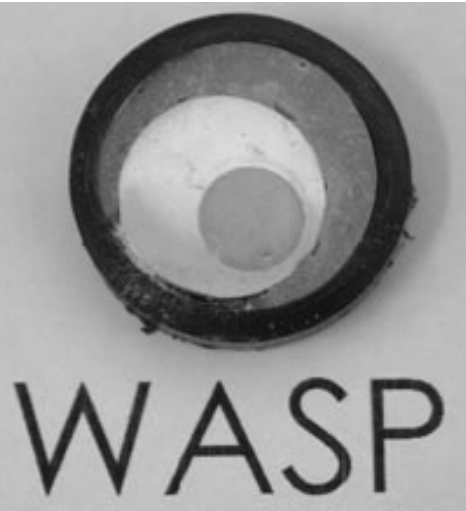

Interface

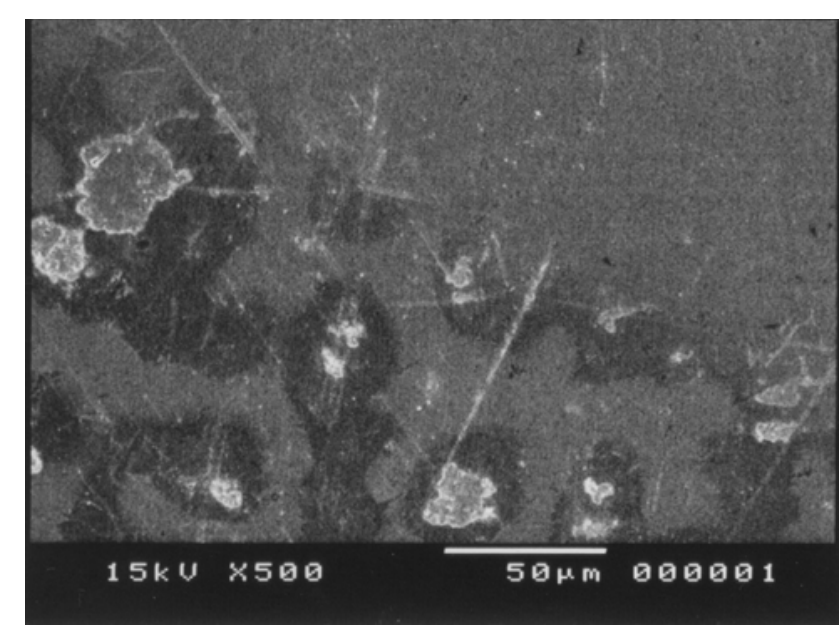

Comoída

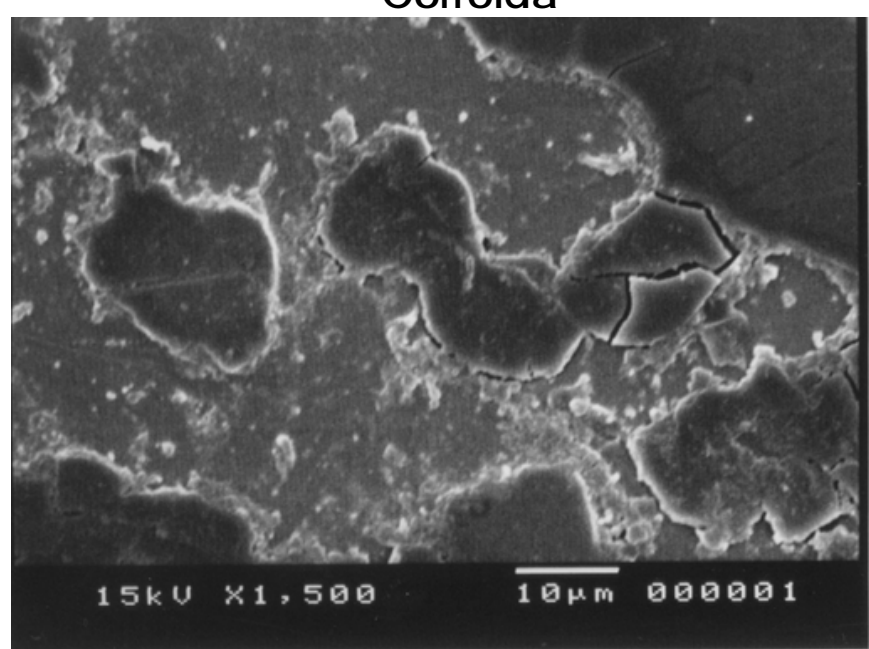

Figura 22 - Amostra após a comosão e fotomicrografias da liga WASP 


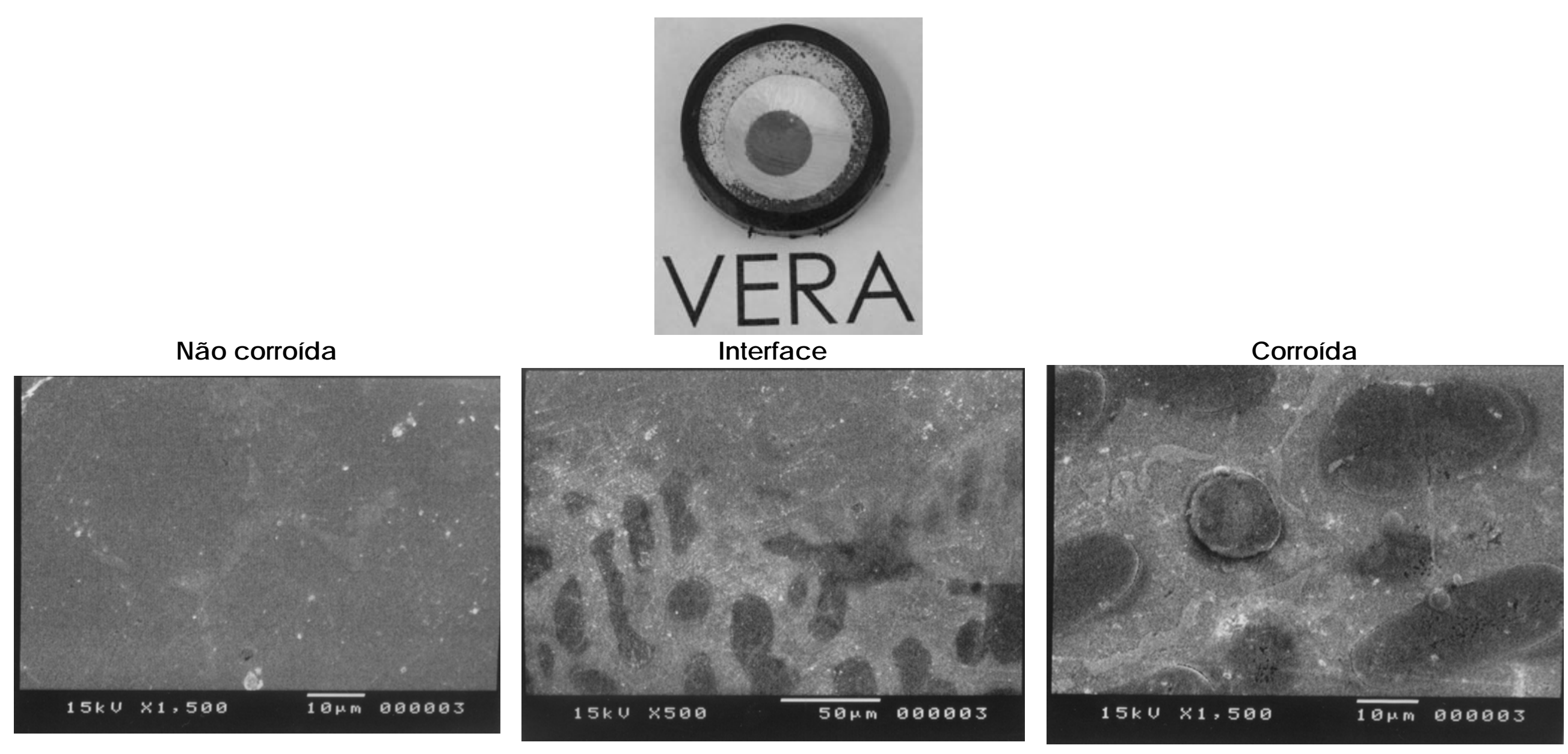

Figura 23 - Amostra após a comosão e fotomicrografias da liga VERA 
6. Discuessão 


\section{Discussão}

Há várias tendências para tratamentos protéticos. Uma dessas tendências são as restaurações livres de metal ou restaurações totalmente cerâmicas devido à crescente valorização dos materiais restauradores estéticos, na busca de restaurações imperceptíveis. Embora apresentem algumas vantagens em algumas aplicações clínicas e proporcionem excelente estética, estas restaurações não são viáveis a substituir a indicação de restaurações metalocerâmicas. Sendo assim, as ligas odontológicas são matéria-prima para muitos trabalhos odontológicos. Esses materiais apresentam propriedades importantes, como alta resistência mecânica, precisão dimensional, alto módulo de elasticidade, que as tornam adequadas a essa indicação. Assim sendo, as ligas ainda ocupam uma importante posição dentre os diversos materiais restauradores disponíveis.

A grande maioria das restaurações estéticas ainda são as metalocerâmicas (GIORDANO, 1996; 2002); estas restaurações têm provado sua durabilidade em longo prazo. Os sistemas restauradores totalmente cerâmicos requerem a remoção significantemente maior de estrutura dental e são mais susceptíveis à fratura, especialmente de dentes posteriores ou na construção de próteses parciais fixas (ANUSAVICE, 1993; DEANY, 1996; ANUSAVICE; ZHANG, 1997). 
Dessa forma, têm-se procurado formular ligas ou mesmo adaptar ligas já existentes no mercado para uso odontológico (MATTOS et al., 1993; BEZZON et al., 1995). Porém, o desenvolvimento de ligas é um processo complexo e requer conhecimento acompanhado de experiências em pesquisa e desenvolvimento. Mesmo as melhores ligas, trabalhadas de maneira inadequada, podem ocasionar problemas intrabucais. Assim, a introdução de novos tipos de ligas tem criado um problema tanto para o laboratório de prótese como para o dentista.

Novas ligas podem ser mais difíceis de fundir, proporcionando fundições imprecisas; ou ainda podem ser difíceis de soldar e polir ou envolvem a estética, o que torna a elaboração de uma restauração protética ainda mais desafiadora. O dentista e o técnico devem avaliar essas complexidades, selecionar o produto que melhor é indicado ao caso clínico e respeitar sua manipulação.

objetivo desse trabalho foi utilizar superligas com quantidades diferentes de titânio em sua composição para uso odontológico. Sabese, porém, que as propriedades que uma liga apresenta depende não apenas de sua composição, mas também da qualidade do método de obtenção destas peças (ANUSAVICE; CASCONE, 2005). Sendo assim, a adoção de uma liga metálica para ser utilizada na Odontologia deve considerar a possibilidade em ser fundida pela técnica da cera perdida, procedimento mais utilizado e melhor dominado pelos técnicos em prótese dental em razão de tratar-se de um procedimento que não 
utiliza equipamentos sofisticados. Além disso, segundo Galo (2004) esse processo não altera as propriedades físicas e químicas dos metais, razão pela qual foi escolhida para obter os corpos-de-prova no presente trabalho.

Porém, os procedimentos de inclusão e fundição devem ser criteriosos e deve-se tomar cuidado com todos os passos que o compõe. Devido à alta temperatura de fusão $\left(1670^{\circ} \mathrm{C}\right)$ e um comportamento ativo quimicamente a altas temperaturas, as fundições de ligas com titânio estão susceptíveis à contaminação com o oxigênio em sua superfície e interação com o revestimento. Essas desvantagens resultam em uma formação de uma superfície endurecida na superfície do revestimento fosfatado (MIYAKAWA et al., 1989). Acredita-se que essa estrutura é formada devido à decomposição do revestimento e difusão dos elementos liberados ao interior da fundição. Essa ocorrência é relatada quando utilizados diferentes tipos de métodos de fundição (TAKAHASHI et al., 1993). Segundo Cai et al. (1999) essa reatividade com o revestimento pode alterar a liberação de íons titânio durante o teste de corrosão, tornando os resultados incertos.

Apesar de se conhecer os efeitos benéficos da atmosfera controlada sobre a qualidade de fundição de ligas com Ti, optou-se pela fusão da liga em maçarico gás/oxigênio pois, segundo Minacci, (2000), analisando as estruturas cristalinas das ligas através de espectrometria de difração de raios $x$, verificou que não houve 
alteração nos estados bruto de laminação e bruto de fundição após sua fusão com maçarico gás/oxigênio. Porém, em análise quantitativa através de fluorescência de raios $x$, encontrou diferença quantitativa dos elementos constituintes de cada liga, de maneira que a porcentagem em massa relativa aos elementos Ti e Al mostrou-se menor nas amostras obtidas através do processo de fundição utilizado. Isso ocorreria em razão da reatividade desses elementos ao oxigênio favorecendo a oxidação dos elementos formando $\mathrm{TiO}_{2}$ e $\mathrm{Al}_{2} \mathrm{O}_{3}$, o que poderia contribuir com a resistência à corrosão.

Os resultados no presente trabalho demonstraram, porém, que as ligas que contêm Ti apresentaram pior desempenho em relação à resistência à corrosão, apresentando maiores valores de $\mathrm{i}_{\text {corr }}$ (Tabela 6). Verifica-se, dessa forma, que a oxidação, por ocasião da fusão da liga, não contribuiu para o aumento da resistência à corrosão. Segundo Galo (2004), a técnica de fundição por chama proporciona às ligas resistência à corrosão superior à técnica de fundição por vácuo. Em contrapartida, a liga sem Ti (VERA), que contêm maior quantidade de Al em relação às demais ligas estudadas, foi a que apresentou melhor resistência à corrosão.

Quanto aos valores de ícorr encontrados em saliva artificial verificou-se que a liga que apresentou maior corrente foi a WASP, indicando maior corrosão, seguida das ligas INC e VAT. A liga VERA 
apresentou a menor corrosão. Esses resultados estão de acordo com os estudos de Benatti et al. (2000).

Para metais e ligas, a corrosão é sempre acompanhada pela liberação de elementos e formação de uma corrente. Toda liga sofrerá alguma corrosão intrabucal, mas há muita variação dessa propriedade, que pode levar a uma diminuição da estética, compromete as propriedades físicas ou aumenta a irritação biológica (JOHANSSON et al., 1989)

A corrosão de ligas pode ser clinicamente visível se esta for severa, muito embora a liberação de elementos continue por meses ou anos após a colocação no ambiente bucal, em níveis baixos (WATAHA et al., 1999).

A corrosão de metais e ligas depende de vários fatores e pode ser determinada por diversos métodos. Benatti et al. (2000) avaliaram o processo corrosivo visualmente por três examinadores calibrados após períodos determinados. Porém, o comportamento corrosivo de ligas é facilmente acompanhado pelo uso de métodos eletroquímicos. A utilização desta técnica permite obter reprodutilibidade de resultados na mesma amostra e é um teste relativamente rápido (DE MICHELI; RIESGO, 1981). Porém, a validade dos resultados obtidos depende das condições experimentais a que as amostras são submetidas. 
Duas técnicas são descritas na norma ISO/10271 (2001) para análise da corrosão: $O$ teste de imersão estático conjugado à análise da solução de corrosão e a medida eletroquímica com o auxílio de uma célula de corrosão, escolhido como metodologia para esse trabalho. Outros autores como Wataha (2002), porém, acredita ser mais relevante avaliar a corrosão pela liberação de elementos para avaliar os efeitos biológicos adversos que a corrosão das ligas pode provocar.

Os testes de resistência à corrosão podem estar associados ao desgaste e segundo Kotomori et al. (2001) é importante considerar essa sinergia entre as propriedades; o desgaste é aumentado pela ação da corrosão e a corrosão aumenta com a ação do desgaste (COOK et al., 1994). Porém, comparado ao número de trabalhos na literatura que abordam o desgaste e a corrosão isoladamente, há poucos trabalhos publicados com os testes associados (MELETIS et al., 1989; KHAN et al., 1996, 1999). A densidade da corrente de corrosão é um pouco menor em superfícies polidas. Porém é nessa circunstância que o material é utilizado no ambiente bucal.

A corrosão é influenciada também por microrganismos, o que se chama de biocorrosão, e isso pode levar a grandes danos às estruturas metálicas. Poucos autores têm estudado essa influência (BRUGIRARD; MAZILLE, 1971; WILSON et al., 1997; LAURENT et al., 2001). 
A utilização de um agente clareador sobre a liga fundida, sem polimento, aumenta a corrosão devido à remoção do filme protetor causado pelo polimento. A superfície não polida é oxidada permitindo uma dissolução química (CANAY et al., 2002). Essa ocorrência torna-se importante, pois tem aumentado o número de pacientes que fazem uso de agentes clareadores e estes podem ter restaurações metálicas em alguns elementos restaurados. A ação desses agentes clareadores pode levar a uma interação indesejada com as ligas produzindo efeitos com significância clínica, inclusive quanto à longevidade da restauração.

Estudo in vivo são difíceis de serem conduzidos, em função do tempo que consome e, principalmente, devido à dificuldade de padronização. Assim as medidas de polarização anódica têm sido realizadas em estudos prévios in vitro. Esse método proporciona informações muito valiosas quanto às reações eletroquímicas em vários potenciais e pode ser usado para comparar comportamentos corrosivos (MATONO; FUSAYAMA, 1972; CANAY; OKTEMER, 1992; PATRO et al., 1998; CANAY et al., 2002).

Para Reclaru; Meyer (1995), a dificuldade encontrada por estudos que utilizam a curva de polarização para estudo da corrosão recai muito mais na definição do ambiente (meio) do que nos parâmetros metalúrgicos da obtenção das amostras. As condições 
atuais conectadas com a natureza química e física do meio corrosivo são, a priori, muito complexos ou mesmo impossíveis de simular.

Uma saliva artificial que reaja com o material testado é um requisito básico para criar um ambiente bucal artificial, de forma a simular o que acontece com a saliva natural. Entende-se que é impossível duplicar exatamente as propriedades da saliva humana devido à inconsistência e instabilidade da saliva natural (MANDEL, 1974). Essa instabilidade também torna a saliva natural inapropriada para o uso em estudos in vitro padronizados (LEUNG; DARVELL, 1997).

A composição e as propriedades da saliva podem ser afetadas por muitas variáveis fisiológicas como fatores nutricionais, a dieta e o fluxo salivar (KEROSUO et al., 1997). De acordo com Edgar et al. (2004), a saliva por ser influenciada também por hormônios, drogas e várias doenças.

As ligas odontológicas estão expostas a diferentes condições ambientais: em contato com osso (implantes), gengiva (sulco gengival) e à saliva, ambientes com maior ou menor quantidade de oxigênio presente. Além disso, as condições ambientais da boca são extremas. Como exemplo, a temperatura a que um material se submete varia entre 5 e $55^{\circ} \mathrm{C}$ e a composição e o pH da saliva varia dependendo da dieta. Além disso, as condições mecânicas a que são submetidos são 
severas e dependem da força dos músculos além da idade do paciente (MUELLER et al., 2005).

A saliva na cavidade bucal é geralmente considerada como sendo um ambiente aerado, ou seja, com presença de oxigênio. As polarizações linear e cíclica são conduzidas em um meio como esse. Entretanto, um ambiente sem oxigênio poderá somente afetar a reação de redução, não a de oxidação. Além disso, certas áreas da cavidade bucal como a região sub-gengival e as áreas sob o biofilme dental são uma região sem oxigênio.

Darvell (1978) desenvolveu uma formulação de saliva artificial para estudos de corrosão com base em norma ISO, que por sua vez está baseada em análise de saliva humana.

Em estudo de Holland (1992) sobre corrosão utilizando vários eletrólitos, os resultados mostraram que a solução de Fusayama foi a mais corrosiva às ligas odontológicas. Entretanto, segundo o mesmo autor, isso não pode ser um critério definitivo na escolha da fórmula de saliva artificial mais apropriada para a realização dos testes, mesmo porque a solução de Fusayama apresenta uma composição ainda diferente da saliva natural, principalmente em relação à maior concentração de uréia e à presença de enxofre.

Grosfogeat et al. (1999); Mareci et al. (2005) utilizaram como meio de corrosão, uma solução de saliva artificial de Afnor (Carter- 
Brugirard AFNOR/NF (French Association of Normalization) 591-141; composição: $\mathrm{NaCl}-0.7 \mathrm{~g} / \mathrm{L}, \mathrm{KCl}-1.2 \mathrm{~g} / \mathrm{L}, \mathrm{Na}_{2} \mathrm{HPO}_{4} \mathrm{H}_{2} \mathrm{O}-0.26 \mathrm{~g} / \mathrm{L}, \mathrm{NaHCO}_{3}$ $-1.5 \mathrm{~g} / \mathrm{L}, \mathrm{KSCN}-0.33 \mathrm{~g} / \mathrm{L}$, Uréia - $1.35 \mathrm{~g} / \mathrm{L}, \mathrm{e} \mathrm{pH}=8)$.

Reclaru; Meyer (1995) utilizaram como meio corrosivo uma saliva artificial de Fusayama a $37^{\circ} \mathrm{C}$ e pH 5 que apresentava a seguinte composição: $\mathrm{NaCl} 0,4 \mathrm{~g} / \mathrm{L} ; \mathrm{KCl}$ 0,4 g/L; $\mathrm{NaHPO}_{4} . \mathrm{H}_{2} \mathrm{O}$ 0,69 g/L; CaCl. $\mathrm{H}_{2} \mathrm{O}$ 0,79 $\mathrm{g} / \mathrm{L}$ e Ureia 1,0 $\mathrm{g} / \mathrm{L}$. Os autores argumentaram que consideraram somente os componentes minerais (exceto a uréia) pois, afirmaram que esse eletrólito não permite simular os efeitos dos componentes orgânicos na saliva natural, muito embora esse eletrólito ter sido utilizado em outros trabalhos e permitido respostas muito próximas das obtidas com saliva natural (MUELLER, 1987). Dessa maneira, optou-se por utilizar uma saliva artificial genérica, sem nenhum componente específico, para que os resultados estivessem o mais próximo à saliva natural.

Metais como Ag, Au, Pd, Cu, Sn, Co e Cr podem ser encontrados na saliva de pacientes que apresentam restaurações com ligas metálicas, sendo que próteses novas liberam mais metal do que as antigas e as maiores liberam mais que as menores (DE MELO et al., 1983).

A comparação do conteúdo de metal da saliva e das ligas revelou que na maioria dos casos (77\%), pelo menos um dos componentes da liga foi encontrado na saliva. Esses dados indicam que 
os componentes das ligas odontológicas são liberados na saliva (GARHAMMER et al., 2004). Uma vez que as ligas odontológicas permanecem na cavidade bucal por um período prolongado de tempo, isso pode causar efeitos adversos como uma conseqüência da corrosão (GEURTSEN, 2002; GARHAMMER et al., 2003). Os produtos da corrosão podem acumular nos tecidos orais e causar um distúrbio gastrointestinal via saliva (STENBERG, 1982; WATAHA, 2000), dentre outros fatores, indicando que a corrosão está claramente relacionada à biocompatibilidade, apesar desse relacionamento ser complexo e difícil de predizer (WATAHA, 2000).

O níquel é o componente principal de muitas ligas estudadas, sendo que sua porcentagem varia de 55 a 65\%. A utilização desse elemento químico em ligas odontológicas é devido ao fato de proporcionar propriedades satisfatórias às necessidades essenciais para uma liga ser utilizada na recolocação dental: resistência à corrosão e resistência mecânica. A liga com cromo e cobalto proporciona propriedades mecânicas aceitáveis em odontologia. Foi demonstrado que o níquel dissolve do aparelho dental na saliva natural, sendo acelerada se o berílio estiver presente na liga (BOURAUEL et al., 1998; IIJIMA et al., 2001). Por outro lado, o níquel é reconhecido como sendo um dos metais mais carcinogênicos na Terra. Assim, ligas que produzem íons de níquel podem gerar câncer devido à absorção desses íons diretamente pela membrana celular. 
O níquel, por sua vez, apresenta a habilidade de se ligar ao oxigênio, nitrogênio e enxofre de compostos biológicos, recolocando os catalisadores usuais (magnésio e cálcio) que são essenciais em muitas atividades metabólicas. Além disso, o níquel é considerado imunossupressivo. Todavia, há 20 anos pelo menos, cerca de $85 \%$ das próteses fixas (coroas) são feitas com ligas à base de Níquel.

Devido a sua excelente resistência à corrosão e biocompatibilidade, o titânio comercialmente puro tem sido adaptado para utilização em odontologia, como um metal para coroas (IDA et al., 1985), restaurações metalocerâmicas (TOGAYA et al., 1983; NILSON et al., 1994) e próteses. Devido à formação instantânea e espontânea de uma camada de óxido em sua superfície, o titânio é altamente resistente à corrosão sob condições estáticas (BOERE, 1995). Porém, mesmo com essa característica, sofrem corrosão e liberam seus produtos para a saliva. O acúmulo seletivo em certos tecidos e a difusão através do organismo podem causar reações desfavoráveis, variando desde uma descoloração do tecido a uma reação severa como osteólise asséptica ou necrose estéril (MAATTA; ARSTILA, 1975; LUGOWSKI et al., 1991; SCHLIEPHAKE et al., 1993).

Em pesquisa na área médica, devido ao aumento do reconhecimento de que, em longo prazo, a recolocação de articulações poderia estar associada a reações adversas locais e sistêmicas que são mediadas pela degradação de produtos 
provenientes do material protético, Jacobs et al. (1998) mediram a concentração de titânio, alumínio, cobalto e cromo no soro e a concentração de cromo na urina de 75 pacientes durante três anos pós-operatórios, em um estudo longitudinal. Vinte pacientes que não tinham implantes foram considerados controle. Os resultados do estudo demonstraram que, após 36 meses pós-operatórios, os pacientes que tiveram um bom funcionamento da prótese com componentes que continham titânio apresentaram uma concentração de titânio no soro três vezes maior, enquanto que aqueles pacientes que tinham próteses com ligas de cobalto apresentaram um aumento de cinco a oito vezes maior dos componentes da liga no soro e na urina, respectivamente. Essa liberação pode ser acelerada devido ao esforço mecânico a que essas próteses se submetem (OKAZAKI; GOTOH, 2005).

Porém, em trabalho de Sedarat et al. (2001) verificando a degradação in vitro de ligas de titânio, não foi encontrada nenhuma reação sistêmica adversa do titânio. Há que se considerar que os elementos que são liberados pelas ligas odontológicas na cavidade bucal não estão dentro do corpo, mas podem ganhar acesso para dentro do corpo através do epitélio e das gengivas. Assim sendo, nenhum estudo com ligas odontológicas demonstrou, em relação aos metais, níveis sistêmicos elevados a partir do uso de restaurações metálicas (WATAHA, 2000). 
Muitas ligas de titânio para uso odontológico incluem como componentes o Alumínio (cerca de 6\%) e o Vanádio (4\%), que apresentam propriedades mecânicas muito similares às ligas de $\mathrm{Ni} / \mathrm{Cr}$ e Co/Cr (WANG; FENTON, 1996). Essas ligas, sofrendo corrosão, liberam os componentes para a saliva quando sofrem corrosão. $\bigcirc$ vanádio, em níveis tóxicos, pode levar a uma reação sistêmica ou inibir a proliferação celular (BARCELOUX, 1999). O alumínio pode estar associado a osteomalácia, granulomatose pulmonar e neurotoxicidade (CHEN et al., 1978; PIERIDES et al., 1980; MARQUIS, 1982).

Não pode-se deixar de considerar que a caracterização apropriada do filme passivo é o primeiro passo para avaliar a biocompatibilidade (NAKAYAMA et al., 1989). Se o filme passivo das ligas odontológicas, normalmente na forma de óxidos, é danificado, aumenta a liberação dos íons e produtos da corrosão para os tecidos subjacentes (HUANG, 2003).

A composição da liga também é muito importante. Por exemplo, em uma liga de Ni/Cr, o potencial do Cr é mais negativo. Porém, o Ni é o elemento responsável pela corrosão dessas ligas, como verificado em diversos estudos anteriores (ESPEVIK, 1978; DE MELO et al., 1985).

É sabido que o Mo e Cr representam componentes de liga que tem contribuição decisiva na corrosão. Assim, sua presença na composição da liga determina o aumento da resistência à corrosão 
(BUMGARDNER; LUCAS, 1993; BAYRAMOGLU et al., 2000; ROACH et al., 2000; MARECl et al., 2005). A liga VERA teve um comportamento como o esperado, ou seja, em sua composição há Mo e seu comportamento frente à corrosão foi melhor em relação às demais ligas estudadas. Porém, a liga WASP que também contem o Mo apresentou a maior corrosão. Isso pode ser explicado pela pouca porcentagem de Mo adicionado à liga. Além disso, grande porcentagem de Co (14\%) é adicionada a essa liga. Isso pode ter levado a uma instabilidade da liga, representada pela maior corrosão.

potencial em circuito aberto (OCP) versus a curva de tempo demonstra os valores que determinam a capacidade da liga em tender à passivação ou dissolver-se no meio. O valor de OCP dessas mesmas ligas diminuiu com o tempo, permitindo concluir que o Mo não contribuiu com a passivação das mesmas. Para a liga VERA, que não apresenta Ti em sua composição, esse comportamento era esperado. Porém para a liga WASP, seu comportamento contraria outros estudos da literatura que indicam que ligas com Mo têm processo de passivação mais intenso (MARECl et al., 2005). Acredita-se que o conteúdo de Co na composição dessa liga pode ter interferido nessa característica e a liga precisaria de mais tempo para atingir uma estabilidade.

Estudos de Jones (1996); Huang (2002), segundo os quais as ligas de Ni/Cr com um conteúdo maior de $\mathrm{Cr}$ e Mo têm uma maior taxa de 
passivação na curva de polarização, concluíram que o comportamento corrosivo dessas ligas na cavidade bucal depende não somente da composição química da liga, mas também na caracterização do filme passivo das ligas. No presente trabalho, os resultados encontrados corroboram os resultados encontrados pelo autor. A liga VERA apresenta pouca quantidade de Mo $(3,5 \%)$ e poderia ter seu comportamento justificado devido a esse fator. Porém, a liga WASP, com maior conteúdo de Mo apresentou resultados piores em relação à liga VERA, sugerindo que só a presença dos elementos Mo e Ti não são garantia de resistência à corrosão. Outros fatores também estão ligados à capacidade de resistir à corrosão.

Verifica-se nos gráficos da Figs. 20 e 21 que as ligas INC e VAT estabilizaram o potencial de corrosão em OCP em poucos minutos, fato diferente das outras duas ligas estudadas, VERA e WASP. Analisando a composição das ligas (Tabela 1) observa-se que as ligas INC e VAT apresentam porcentagens de Ti muito próximas, respectivamente 2,5 e $2,4 \%$, sugerindo que porcentagens maiores de Ti incorporadas nas ligas podem significar uma perda na resistência à corrosão. Esses resultados estão de acordo com os estudos de Espevik (1978), segundo o qual ligas de Ni/Cr com baixas concentrações de Ti não apresentaram variações na resistência à corrosão.

O comportamento das ligas WASP e VERA quanto ao potencial em circuito aberto (Eocp) estaria ligado ao método de fusão da liga. 
Como não é possível um controle rigoroso da temperatura com a utilização de maçarico, os componentes metálicos das ligas não apresentaram homogeneidade após a fusão, podendo apresentar maior concentração de $\mathrm{Cr}$ na superfície, gerando a formação de $\mathrm{Cr} / \mathrm{O}$ ou $\mathrm{Cr} / \mathrm{OH}$ facilitando sua liberação ao meio e impedindo sua ação como agente passivador (BAYRAMOGLU et al., 2000; HUANG, 2003).

A verificação de $E_{o c p}$ e $E_{i}=0$ são medidas de potenciais quando não há corrente. Quanto mais próximos estão esses valores, melhor o comportamento da liga quanto à corrosão. Sendo assim, a liga VERA é a que apresenta valores mais próximos, seguida das ligas WASP, INC e VAT respectivamente, comprovando os outros resultados do trabalho. Em todos os casos, os valores determinados para o potencial de corrosão $\left(E_{i=0}\right)$ são menores do que os correspondentes a $E_{o c p}$ (Tabelas 3 e 4). Essa variação é provavelmente devido ao fenômeno da depassivação na superfície durante a reação catódica. Porém, o valor do potencial de corrosão depende de duas reações parciais: catódica e anódica. Isso explica porque o meio se torna tão importante no processo. Em um meio agressivo, um meio oxidante, a corrente catódica correspondente a um dado valor de potencial é maior e, conseqüentemente, o potencial de corrosão apresentará maiores valores. Nesse caso, a corrente de corrosão aumentará. Há um limite, entretanto, se o metal sofrer passivação: um aumento no poder oxidante do meio poderá reduzir a corrosão. 
No caso de um metal passivo, a corrente anódica medida em função do potencial exibe um pico que separa a fase ativa (metal em contato direto com o eletrólito) da fase passiva do metal (metal coberto por um filme óxido).

A principal alteração que a liga sofre durante o processo de fundição é o aumento da rugosidade superficial, o que está diretamente ligado à resistência à corrosão (HERO, 1984; LEE; CHANG, 2001), de forma que quanto maior a rugosidade superficial menor a resistência à corrosão (BOURAUEL et al., 1998). Isso pode ser comprovado com as imagens das fotomicrografias. A liga VERA, que apresentou menor rugosidade superficial antes do ensaio de corrosão (Fig. 28) apresentou também maior resistência à corrosão (Tabela 8).

Um conceito metalúrgico importante à performance clínica das ligas é sua estrutura de fases (também chamado de microestrutura, que inclui a estrutura de grãos das ligas). Ligas podem ser de fase simples ou múltiplas fases. Um liga de fase simples tem essencialmente a mesma composição em toda parte, enquanto que as ligas de múltiplas fases têm áreas microestruturais de composições diferentes. Dependendo se uma liga é de fase simples ou de múltiplas fases há uma interferência em sua solubilidade quanto aos elementos da liga (BARAN, 2004). Se todos os elementos são completamente solúveis entre si no estado sólido (como no caso do ouro, paládio e cobre), então a liga será de 
fase simples. Se alguns elementos não são solúveis entre si (como no caso do ouro e platina), então a liga poderá ser de múltiplas fases.

A estrutura de fases afeta a corrosão, resistência e outras características das ligas. Em geral, ligas de múltiplas fases têm a tendência de maior corrosão do que as de fases simples (RECLARU; MEYER, 1995), devido ao efeito galvânico entre as áreas microscópicas das diferentes composições (WATAHA et al., 1991; BUMGARDNER; LUCAS, 1994). Além disso, a maior porcentagem de elementos não nobres faz, aumentar o risco de corrosão (WATAHA; LOCKWOOD, 1998; WATAHA, 2000).

A análise metalográfica das ligas realizada por Monacci (2000) revelou características de suas microestruturas. A liga VAT não apresentou grãos bem delineados e homogêneos em termos de distribuição dos elementos da liga. A liga INC mostrou grãos bem delineados com carbonetos de titânio e nióbio nos contornos e no interior dos grãos. A liga WASP apresentou células dendríticas de solidificação com acentuada microssegregação. No contorno dos grãos foram observados carbonetos de titânio.

Independente da composição das ligas, todas sofreram considerável corrosão. É possível observar bem delimitada a interface da região corroída/não-corroída. Pode ser visto pelas fotomicrografias (Figs. 25 a 28) que houve mudança acentuada nas características 
estruturais das diferentes ligas. Verificou-se, principalmente para as ligas WASP (Fig. 22) e VERA (Fig. 23), que após a corrosão, as ligas apresentaram características bifásicas. Segundo Mondelli (1995), a segregação de fases pode estar relacionado à técnica de fundição com maçarico gás/ar. Caso não haja controle rigoroso da chama, pode haver a formação de $\mathrm{TiO}_{2}$ e $\mathrm{Al}_{2} \mathrm{O}_{3}$, respectivamente para as ligas WASP e VERA, o que pode contribuir para a segregação. Acredita-se que o mesmo não ocorra com as outras duas ligas com Ti (VAT e INC) devido à concentração que esse elemento ocupa na composição da liga. A maior concentração de Ti na liga WASP (3\%) poderia exceder o limite necessário para proporcionar ligas com características mais homogêneas.

No futuro, para o desenvolvimento de novas ligas, um esforço deveria ser feito para obter-se maior entendimento das interações entre a superfície do metal e o ambiente, principalmente quanto à interdependência entre as características físicas e químicas da superfície da liga e o ambiente corrosivo. 
7. Conclusão 


\section{Conclusão}

- Independentemente da composição das ligas, todas sofreram corrosão.

- As ligas INC e VAT apresentaram estabilização mais rápida com o meio corrosivo sugerindo maior passivação das ligas.

- Quando Ei=0, o comportamento das ligas foi semelhante.

- A liga VERA apresentou maior resistência à corrosão (menor icorr) enquanto que a liga WASP apresentou a menor resistência (maior icorr). As ligas INC e VAT apresentaram comportamento intermediário às duas, com valores de icorr estatisticamente diferentes somente da liga WASP.

- As fotomicrografias revelaram vários graus de rugosidade e porosidade na superfície das ligas. Verifica-se, de maneira muito clara, a diferença das superfícies corroídas e não corroídas.

- As ligas WASP e VERA apresentaram características bifásicas após a corrosão.

- A quantidade de $\mathrm{Ti}$ parece interferir na resistência à corrosão e na segregação de fases da liga pós-corrosão. 
- O comportamento corrosivo das ligas estudadas depende não somente da composição química da liga, mas também na caracterização do filme passivo das ligas. 
8. Referências Gibliográficas 


\section{Referências Bibliográficas}

ADELL, R., LEKHOLM, U., ROCKLER, B., et al. A 15-year study of osseointegrated implants in the treatment of the edentulous jaw. Int J Oral Surg, v.10, n.6, Dec, p.387-416. 1981.

ANUSAVICE, K. J. Recent developments in restorative dental ceramics. $\underline{J}$ Am Dent Assoc, v.124, n.2, Feb, p.72-4, 76-8, 80-4. 1993.

ANUSAVICE, K. J.;CASCONE, P. Fundição Odontológica e Soldagem de Ligas. In: K. J. Anusavice (Ed.). Phillips Materiais Dentários Rio de Janeiro: Elsevier, 2005. Fundição Odontológica e Soldagem de Ligas, p.533 - 586

ANUSAVICE, K. J.;ZHANG, N. Z. Chemical durability of Dicor and lithiabased glass-ceramics. Dent Mater, v.13, n.1, Jan, p.13-9. 1997.

BARAN, G. R. The metallurgy of Ni-Cr alloys for fixed prosthodontics. $\underline{J}$ Prosthet Dent, v.50, n.5, Nov, p.639-50. 1983.

. Ligas metálicas fundidas e trefiladas. In: R. G. Craig e J. M. Powers (Ed.). Materiais Dentários Restauradores. São Paulo: Livraria Editora Santos, 2004. Ligas metálicas fundidas e trefiladas, p.479-514

BARCELOUX, D. G. Vanadium. J Toxicol Clin Toxicol, v.37, n.2, p.265-78. 1999.

BAYRAMOGLU, G., ALEMDAROGLU, T., KEDICl, S., et al. The effect of pH on the corrosion of dental metal alloys. J Oral Rehabil, v.27, n.7, Jul, p.563-75. 2000.

BENATTI, O. F., MIRANDA, W. G., JR.;MUENCH, A. In vitro and in vivo corrosion evaluation of nickel-chromium- and copper-aluminum-based alloys. J Prosthet Dent, v.84, n.3, Sep, p.360-3. 2000.

BEZZON, O. L., ROLLO, J. M. D. A., PANZERI, H., et al. Desenvolvimento de uma liga experimental de níquel-cromo para restaurações metalocerâmicas: ensaios de dureza e resistência mecânica. Rev Odonto USP, v.9, n.2, p.145-149. 1995.

BOERE, $G$. Influence of fluoride on titanium in an acidic environment measured by polarization resistance technique. J Appl Biomater, v.6, n.4, Winter, p.283-8. 1995. 
BOURAUEL, C., FRIES, T., DRESCHER, D., et al. Surface roughness of orthodontic wires via atomic force microscopy, laser specular reflectance, and profilometry. Eur J Orthod, v.20, n.1, Feb, p.79-92. 1998.

BRUGIRARD, J.;MAZILLE, H. [Electrochemical behavior of certain dental metals and alloys]. Chir Dent Fr, v.41, n.51, Jan 20, p.33-51. 1971.

BUMGARDNER, J. D.;LUCAS, L. C. Surface analysis of nickel-chromium dental alloys. Dent Mater, v.9, n.4, Jul, p.252-9. 1993. . Corrosion and cell culture evaluations of nickel-chromium dental casting alloys. J Appl Biomater, v.5, n.3, p.203-13. 1994.

CABRINI, M., CIGADA, A., RONDELLI, G., et al. Effect of different surface finishing and of hydroxyapatite coatings on passive and corrosion current of Ti6Al4V alloy in simulated physiological solution. Biomaterials, v.18, n.11, Jun, p.783-7. 1997.

CAI, Z., NAKAJIMA, H., WOLDU, M., et al. In vitro corrosion resistance of titanium made using different fabrication methods. Biomaterials, v.20, n.2, Jan, p.183-90. 1999.

CANAY, S., CEHRELI, M. C.;BILGIC, S. In vitro evaluation of the effect of a current bleaching agent on the electrochemical corrosion of dental alloys. J Oral Rehabil, v.29, n.10, Oct, p.1014-9. 2002.

CANAY, S.;OKTEMER, M. In vitro corrosion behavior of 13 prosthodontic alloys. Quintessence Int, v.23, n.4, Apr, p.279-87. 1992.

CHEN, W. J., MONNAT, R. J., JR., CHEN, M., et al. Aluminum induced pulmonary granulomatosis. Hum Pathol, v.9, n.6, Nov, p.705-11. 1978.

CHERN LIN, J. H., LO, S. J.;JU, C. P. Biocorrosion study of titanium-nickel alloys. J Oral Rehabil, v.23, n.2, Feb, p.129-34. 1996.

COOK, S. D., BARRACK, R. L.;CLEMOW, A. J. Corrosion and wear at the modular interface of uncemented femoral stems. J Bone Joint Surg Br, v.76, n.1, Jan, p.68-72. 1994.

COSTA E SILVA, A. L.;MEI, P. R. Metais e ligas especiais. In: A. L. Costa E Silva e P. R. Mei (Ed.). Accos e ligas especiais. Sumaré - SP, 1988. Metais e ligas especiais, p.315-337. (Eletrometal S.A Metais Especiais)

DARVELL, B. W. The development of an artificial saliva for in vitro amalgam corrosion studies. J Oral Rehabil, v.5, n.1, Jan, p.41-9. 1978. 
DE MELO, J. F., GJERDET, N. R.;ERICHSEN, E. S. Metal release from cobaltchromium partial dentures in the mouth. Acta Odontol Scand, v.41, n.2, p.71-4. 1983.

. The effect of abrasion on corrosion of dental Co-Cr alloys. An in vitro study. Acta Odontol Scand, v.43, n.2, May, p.69-73. 1985.

DE MICHELI, D. M.;RIESGO, D. [Electrochemical behavior of chromiumcobalt and nickel-chromium dental alloys used in fixed prosthetics]. Dent Press, v.17, n.1, Jan-Feb, p.24-9. 1981.

DEANY, I. L. Recent advances in ceramics for dentistry. Crit Rev Oral Biol Med, v.7, n.2, p.134-43. 1996.

DEMIREL, F., SAYGILI, G.;SAHMALI, S. Corrosion susceptibility of titanium covered by dental cements. J Oral Rehabil, v.30, n.12, Dec, p.1162-7. 2003.

EDGAR, W. M., DAWES, C.;O'MULLANE, D. M. Saliva and oral health. London: British Dental Journal. 2004

ERICSSON, I., LEKHOLM, U., BRANEMARK, P. I., et al. A clinical evaluation of fixed-bridge restorations supported by the combination of teeth and osseointegrated titanium implants. J Clin Periodontol, v.13, n.4, Apr, p.307-12. 1986.

ESPEVIK, S. Corrosion of base metal alloys in vitro. Acta Odontol Scand, v.36, n.3, p.113-7. 1978.

GALO, R. Avaliação do efeito da fundição sobre a resistência à corrosão de ligas odontológicas. Departamento de Materiais Dentários e Prótese - Faculdade de Odontologia de Ribeirão Preto, Universidade de São Paulo (Mestrado), Ribeirão Preto, 2004. 92 p.

GARHAMMER, P., HILLER, K. A., REITINGER, T., et al. Metal content of saliva of patients with and without metal restorations. Clin Oral Investig, v.8, n.4, Dec, p.238-42. 2004.

GARHAMMER, P., SCHMALZ, G., HILLER, K. A., et al. Metal content of biopsies adjacent to dental cast alloys. Clin Oral Investig, v.7, n.2, Jun, p.92-7. 2003.

GEIS-GERSTORFER, J. In vitro corrosion measurements of dental alloys. $\underline{\mathrm{J}}$ Dent, v.22, n.4, Aug, p.247-51. 1994. 
GENTIL, V. Corrosão. Rio de Janeiro: Livros Técnicos e Científicos Editora S.A. 1996. 345 p.

GEURTSEN, W. Biocompatibility of dental casting alloys. Crit Rev Oral Biol Med, v.13, n.1, p.71-84. 2002.

GIORDANO, R. A. Dental ceramic restorative systems. Compend Contin Educ Dent, v.17, n.8, Aug, p.779-82, 784-6 passim; quiz 794. 1996.

A comparison of all-ceramic restorative systems. J Mass Dent Soc, v.50, n.4, Winter, p.16-20. 2002.

GROSGOGEAT, B., RECLARU, L., LISSAC, M., et al. Measurement and evaluation of galvanic corrosion between titanium/Ti6A 14V implants and dental alloys by electrochemical techniques and auger spectrometry. Biomaterials, v.20, n.10, May, p.933-41. 1999.

GUILHERME, A. S., HENRIQUES, G. E., ZAVANELLI, R. A., et al. Surface roughness and fatigue performance of commercially pure titanium and Ti-6Al-4V alloy after different polishing protocols. J Prosthet Dent, v.93, n.4, Apr, p.378-85. 2005.

HANSEN, M.;ANDERKO, K. Constitution of binary alloys. New York: Mc Graw-Hill. 1958. 1110 p.

HARCOURT, H. J., RIDDIHOUGH, M.;OSBORNE, J. The properties of nickelchromium casting alloys containing boron and silicon. $\mathrm{Br}$ Dent J, v.129, n.9, Nov 3, p.419-23. 1970.

$\mathrm{HERO}, \mathrm{H}$. Effects of casting temperature on some properties of $\mathrm{Co}-\mathrm{Cr}-\mathrm{Mo}$ dental casting alloys. Acta Odontol Scand, v.42, n.6, Dec, p.371-7. 1984.

HOLLAND, R. I. Corrosion testing by potentiodynamic polarization in various electrolytes. Dent Mater, v.8, n.4, Jul, p.241-5. 1992.

HRUSKA, A. R.;BORELLI, P. Quality criteria for pure titanium casting, laboratory soldering, intraoral welding, and a device to aid in making uncontaminated castings. J Prosthet Dent, v.66, n.4, Oct, p.561-5. 1991.

HUANG, H. H. Effect of chemical composition on the corrosion behavior of Ni-Cr-Mo dental casting alloys. J Biomed Mater Res, v.60, n.3, Jun 5, p.458-65. 2002.

- Surface characterization of passive film on NiCr-based dental casting alloys. Biomaterials, v.24, n.9, Apr, p.1575-82. 2003. 
HUGET, E. F., DVIVEDI, N.;COSNER, H. E., JR. Properties of two nickelchromium crown-and-bridge alloys for porcelain veneering. J Am Dent Assoc, v.94, n.1, Jan, p.87-90. 1977.

IDA, K., TANI, Y., TSUTSUMI, S., et al. Clinical application of pure titanium crowns. Dent Mater J, v.4, n.2, Dec, p.191-5. 1985.

IIJIMA, M., ENDO, K., OHNO, H., et al. Corrosion behavior and surface structure of orthodontic Ni-Ti alloy wires. Dent Mater J, v.20, n.1, Mar, p.103-13. 2001.

ISO/10271. Dental Metallic Materials - Corrosion Test Methods. Iso. Geneve - Swiss 2001.

JACOBS, J. J., SKIPOR, A. K., PATTERSON, L. M., et al. Metal release in patients who have had a primary total hip arthroplasty. A prospective, controlled, longitudinal study. J Bone Joint Surg Am, v.80, n.10, Oct, p.1447-58. 1998.

JOHANSSON, B. I., LEMONS, J. E.;HAO, S. Q. Corrosion of dental copper, nickel, and gold alloys in artificial saliva and saline solutions. Dent Mater, v.5, n.5, Sep, p.324-8. 1989.

JONES, D. A. Principles and prevention of corrosion. Englewood Cliffs, NJ: Prentice-Hall. 1996.513-551 p.

KEDICI, S. P., AKSUT, A. A., KILICARSLAN, M. A., et al. Corrosion behaviour of dental metals and alloys in different media. J Oral Rehabil, v.25, n.10, Oct, p.800-8. 1998.

KEROSUO, H., MOE, G.;HENSTEN-PETTERSEN, A. Salivary nickel and chromium in subjects with different types of fixed orthodontic appliances. Am J Orthod Dentofacial Orthop, v.111, n.6, Jun, p.595-8. 1997.

KHAN, M. A., WILLIAMS, R. L.;WILLIAMS, D. F. In-vitro corrosion and wear of titanium alloys in the biological environment. Biomaterials, v.17, n.22, Nov, p.2117-26. 1996.

. Conjoint corrosion and wear in titanium alloys. Biomaterials, v.20, n.8, Apr, p.765-72. 1999.

KOIKE, M.;FUJII, $H$. The corrosion resistance of pure titanium in organic acids. Biomaterials, v.22, n.21, Nov, p.2931-6. 2001. 
KOMOTORI, J., LEE, B. J., DONGB, H., et al. Corrosion response of surface engineered titanium alloys damaged by prior abrasion. Wear v.251, p.1239-1249. 2001.

LAKHTIN, Y. Engineering physical metalurgy. Moscou: Foreing Language Publishing House. 1970

LAURENT, F., GROSGOGEAT, B., RECLARU, L., et al. Comparison of corrosion behaviour in presence of oral bacteria. Biomaterials, v.22, n.16, Aug, p.2273-82. 2001.

LAUTENSCHLAGER, E. P.;MONAGHAN, P. Titanium and titanium alloys as dental materials. Int Dent J, v.43, n.3, Jun, p.245-53. 1993.

LEDVINA, M.;RIGNEY, E. D. The thin electrolyte layer approach to corrosion testing of dental materials--characterization of the technique. Biomaterials, v.19, n.23, Dec, p.2201-7. 1998.

LEE, J. D. Fundamentos de química inorgânica. São Paulo: Edgard Blucher. 1971. $248 \mathrm{p}$.

LEE, S. H.;CHANG, Y. I. Effects of recycling on the mechanical properties and the surface topography of nickel-titanium alloy wires. Am J Orthod Dentofacial Orthop, v.120, n.6, Dec, p.654-63. 2001.

LEUNG, V. W.;DARVELL, B. W. Artificial salivas for in vitro studies of dental materials. J Dent, v.25, n.6, Nov, p.475-84. 1997.

LUGOWSKI, S. J., SMITH, D. C., MCHUGH, A. D., et al. Release of metal ions from dental implant materials in vivo: determination of $\mathrm{Al}, \mathrm{Co}, \mathrm{Cr}, \mathrm{Mo}, \mathrm{Ni}$, $\mathrm{V}$, and Ti in organ tissue. J Biomed Mater Res, v.25, n.12, Dec, p.1443-58. 1991.

MAATTA, K.;ARSTILA, A. U. Pulmonary deposits of titanium dioxide in cytologic and lung biopsy specimens. Light and electron microscopic $\mathrm{x}$ ray analysis. Lab Invest, v.33, n.3, Sep, p.342-6. 1975.

MANDEL, I. D. Relation of saliva and plaque to caries. J Dent Res, v.53, n.2, Mar-Apr, p.246-66. 1974.

MARECl, D., NEMTOI, G., AELENEl, N., et al. The electrochemical behaviour of various non-precious $\mathrm{Ni}$ and $\mathrm{Co}$ based alloys in artificial saliva. Eur Cell Mater, v.10, Jul 8, p.1-7; discussion 1-7. 2005. 
MARQUIS, J. K. Aluminum neurotoxicity: an experimental perspective. Bull Environ Contam Toxicol, v.29, n.1, Jul, p.43-9. 1982.

MATONO, R.;FUSAYAMA, T. Corrosion of amalgam in contact with gold. $\underline{\mathrm{J}}$ Prosthet Dent, v.28, n.2, Aug, p.170-8. 1972.

MATTOS, M. G. C., BEZZON, O. L., FREGONESI, L. A., et al. Análise qualitativa da pureza dos elementos metálicos constituintes de uma liga experimental de Co-Cr-Ni-Ti. Rev Odonto USP, v.7, n.2, p.93-95. 1993.

MCLEAN, J. W. The metal-ceramic restoration. Dent Clin North Am, v.27, n.4, Oct, p.747-61. 1983.

MELETIS, E. I., GIBBS, C. A.;LIAN, K. New dynamic corrosion test for dental materials. Dent Mater, v.5, n.6, Nov, p.411-4. 1989.

MEYER, J. M., PAYAN, J.;NALLY, J. N. Evaluation of alternative alloys to precious ceramic alloys. 1. Mechanical properties. J Oral Rehabil, v.6, n.3, Jul, p.291-309. 1979.

MILLER, D. R. Stoloff,Ns - Mechanical Properties of Ordered Alloys. Journal of the Australian Institute of Metals, v.11, n.3, p.215-\&. 1966.

MIYAKAWA, O., WATANABE, K., OKAWA, S., et al. Layered structure of cast titanium surface. Dent Mater J, v.8, n.2, Dec, p.175-85. 1989.

MOFFA, J. P. Alternative dental casting alloys. Dent Clin North Am, v.27, n.4, Oct, p.733-46. 1983.

MOFFA, J. P.;JENKINS, W. A. Status report on base-metal crown and bridge alloys. J Am Dent Assoc, v.89, n.3, Sep, p.652-5. 1974.

MOFFA, J. P., LUGASSY, A. A., GUCKES, A. D., et al. An evaluation of nonprecious alloys for use with porcelain veneers. Part I. Physical properties. J Prosthet Dent, v.30, n.4, Oct, p.424-31. 1973.

MONACCl, A. C. Ligas de Níquel-Cromo contendo Titânio: avaliação de algumas propriedades físicas e químicas. Departamento de Materiais Dentários e Prótese - Faculdade de Odontologia de Ribeirão Preto, Universidade de São Paulo (Mestrado), Ribeirão Preto, 2000. 112 p.

MONDELLI, J. Ligas alternativas para restaurações fundidas. São Paulo: Panamericana. 1995. $353 \mathrm{p}$. 
MORRIS, H. F. Veterans Administration Cooperative Studies Project No. 147/242. Part VII: The mechanical properties of metal ceramic alloys as cast and after simulated porcelain firing. J Prosthet Dent, v.61, n.2, Feb, p.160-9. 1989.

MORRIS, H. F., MANZ, M., STOFFER, W., et al. Casting alloys: the materials and "The Clinical Effects". Adv Dent Res, v.6, Sep, p.28-31. 1992.

MUELLER, H. J. Tarnish and corrosion of dental alloys. In: A. I. H. Committee (Ed.). Metals Handbook, v.13 - Corrosion, 1987. Tarnish and corrosion of dental alloys, p.1336-1360

MUELLER, W. D., SCHOEPF, C., NASCIMENTO, M. L., et al. Electrochemical characterisation of dental alloys: its possibilities and limitations. Anal Bioanal Chem, v.381, n.8, Apr, p.1520-5. 2005.

MULDERS, C., DARWISH, M.;HOLZE, R. The influence of alloy composition and casting procedure upon the corrosion behaviour of dental alloys: an in vitro study. J Oral Rehabil, v.23, n.12, Dec, p.825-31. 1996.

NAKAYAMA, Y., YAMAMURO, T., KOTOURA, Y., et al. In vivo measurement of anodic polarization of orthopaedic implant alloys: comparative study of in vivo and in vitro experiments. Biomaterials, v.10, n.6, Aug, p.420-4. 1989.

NEVILLE, A.;MCDOUGALL, B. A. B. Erosion - and cavitation - corrosion of titanium and its alloys. Wear, v.250, p.726-735. 2001.

NILSON, H., BERGMAN, B., BESSING, C., et al. Titanium copings veneered with Procera ceramics: a longitudinal clinical study. Int J Prosthodont, v.7, n.2, Mar-Apr, p.115-9. 1994.

OKAZAKI, Y.;GOTOH, E. Comparison of metal release from various metallic biomaterials in vitro. Biomaterials, v.26, n. 1, Jan, p.11-21. 2005.

PASCHOAL, A. L., VANANCIO, E. C., CANALE LDE, C., et al. Metallic biomaterials TiN-coated: corrosion analysis and biocompatibility. Artif Organs, v.27, n.5, May, p.461-4. 2003.

PATRO, T. K., SINGH, B. P.;SINGH, V. Corrosion behaviour of an indigenous Ag-Sn-Cu cast dental alloy in artificial saliva. J Oral Rehabil, v.25, n.4, Apr, p.292-8. 1998. 
PIERIDES, A. M., EDWARDS, W. G., JR., CULLUM, U. X., JR., et al. Hemodialysis encephalopathy with osteomalacic fractures and muscle weakness. Kidney Int, v.18, n.1, Jul, p.115-24. 1980.

POLUKTHIN, P. Metal process engineering. Moscou: Peace Publisher. 1970

PRESSWOOD, R. G., SKJONSBY, H. S., HOPKINS, G., et al. A base metal alloy for ceramo-metal restorations. J Prosthet Dent, v.44, n.6, Dec, p.6249. 1980.

RECLARU, L.;MEYER, J. M. Study of corrosion between a titanium implant and dental alloys. J Dent, v.22, n.3, Jun, p.159-68. 1994.

Zonal coulometric analysis of the corrosion resistance of dental alloys. J Dent, v.23, n.5, Oct, p.301-11. 1995.

. Effects of fluorides on titanium and other dental alloys in dentistry. Biomaterials, v.19, n.1-3, Jan-Feb, p.85-92. 1998.

ROACH, M. D., WOLAN, J. T., PARSELL, D. E., et al. Use of x-ray photoelectron spectroscopy and cyclic polarization to evaluate the corrosion behavior of six nickel-chromium alloys before and after porcelain-fused-to-metal firing. J Prosthet Dent, v.84, n.6, Dec, p.623-34. 2000.

RONDELLI, G.;VICENTINI, B. Localized corrosion behaviour in simulated human body fluids of commercial Ni-Ti orthodontic wires. Biomaterials, v.20, n.8, Apr, p.785-92. 1999.

SCHIFF, N., GROSGOGEAT, B., LISSAC, M., et al. Influence of fluoride content and $\mathrm{pH}$ on the corrosion resistance of titanium and its alloys. Biomaterials, v.23, n.9, May, p.1995-2002. 2002.

SCHLIEPHAKE, H., REISS, G., URBAN, R., et al. Metal release from titanium fixtures during placement in the mandible: an experimental study. Int J Oral Maxillofac Implants, v.8, n.5, p.502-11. 1993.

SCHRIEVER, W.;DIAMOND, L. E. Electromotive forces and electric currents caused by metallic dental fillings. J Dent Res, v.31, n.2, Apr, p.205-29. 1952.

SEDARAT, C., HARMAND, M. F., NAJI, A., et al. In vitro kinetic evaluation of titanium alloy biodegradation. J Periodontal Res, v.36, n.5, Oct, p.269-74. 2001. 
STENBERG, T. Release of cobalt from cobalt chromium alloy constructions in the oral cavity of man. Scand J Dent Res, v.90, n.6, Dec, p.472-9. 1982.

STRIETZEL, R., HOSCH, A., KALBFLEISCH, H., et al. In vitro corrosion of titanium. Biomaterials, v.19, n.16, Aug, p.1495-9. 1998.

TAKAHASHI, J., ZHANG, J. Z.;OKAZAKI, M. Effect of casting methods on castability of pure titanium. Dent Mater J, v.12, n.2, Dec, p.245-52. 1993.

TOGAYA, T., SUZUKI, M., TSUTSUMI, S., et al. An application of pure titanium to the metal porcelain system. Dent Mater J, v.2, n.2, Dec, p.2109. 1983.

TURPIN, Y. L., TARDIVEL, R. D., TALLEC, A., et al. Corrosion susceptibility of titanium covered by dental cements. Dent Mater, v.16, n.1, Jan, p.57-61. 2000.

WANG, R. R.;FENTON, A. Titanium for prosthodontic applications: a review of the literature. Quintessence Int, v.27, n.6, Jun, p.401-8. 1996.

WATAHA, J. C. Biocompatibility of dental casting alloys: a review. J Prosthet Dent, v.83, n.2, Feb, p.223-34. 2000.

Alloys for prosthodontic restorations. J Prosthet Dent, v.87, n.4, Apr, p.351-63. 2002.

WATAHA, J. C., CRAIG, R. G.;HANKS, C. T. The release of elements of dental casting alloys into cell-culture medium. J Dent Res, v.70, n.6, Jun, p.1014-8. 1991.

WATAHA, J. C.,LOCKWOOD, P. E. Release of elements from dental casting alloys into cell-culture medium over 10 months. Dent Mater, v.14, n.2, Mar, p.158-63. 1998.

WATAHA, J. C., LOCKWOOD, P. E., NELSON, S. K., et al. Long-term cytotoxicity of dental casting alloys. Int J Prosthodont, v.12, n.3, May-Jun, p.242-8. 1999.

WEST, J. M. Eletrodeposition and corrosion process. London. 1970. 1-47 p.

WILSON, M., PATEL, H., KPENDEMA, H., et al. Corrosion of the intra-oral magnets by multi-species biofilms in the presence and absence of sucrose. Biomaterials, v.18, n.1, Jan, p.53-7. 1997. 
WINKLER, S., MORRIS, H. F.;MONTEIRO, J. M. Changes in mechanical properties and microstructure following heat treatment of a nickelchromium base alloy. J Prosthet Dent, v.52, n.6, Dec, p.821-7. 1984.

WOLYNEC, S. Técnicas eletroquímicas em corrosão. São Paulo: Editora da Universidade de São Paulo. 2003. 176 p. 